\section{Peran Satuan Intelkam Dalam Mencegah \\ Paham Radikal di Masyarakat Melalui Deradikalisasi (Studi Pada Satuan Intelkam Polres Deli Serdang.}

oleh :

\section{Rahmad Hutagaol ${ }^{1}$}

\section{Abstract}

Deli Serdang Resort Police Jurisdiction has done its role in effort to image and develop radical understanding to the community by involving all components as well as deradicalizing groups or people who have committed radical/ terrorist act so that the group or person is aware of their mistakes and omission for action that can harm the integrity of the nation and state. In addition to this, Deli Serdang Resort Police also conducted various de-radicalization programs.

The problem formulated in the formulation of the problem is how Deli Serdang Resort Police Intelligence Unit plays a role in preventing radical understanding through deradicalization. What are the efforts made by Deli Serdang Resort Police Intelligence Unit in preventing radical understanding through deradicalization? Are there obstacles in Deli Serdang Resort Police Intelligence Unit in preventing radical ideology through deradicalization? The approach taken is to use the normative juridical method. The juridical normative approach method is used to examine library materials which are primary data. Based on the data obtained, then an analysis is done to draw conclusion after being described in detail based on available sources.

The results of this study are the role of Deli SerdangResort Police Intelligence Unit in preventing radical understanding through deradicalization. The role of Deli Serdang Resort Police Intelligence Unit is to monitor the movement of the community and community groups so that they do not follow radical ideas, provide counseling, conduct communityand

\footnotetext{
${ }^{1}$ Alumni Magister Hukum Fakultas Hukum UISU
}

religious activities. Efforts made by Deli Serdang Resort Police Intelligence Unit in preventing radical ideology through deradicalism are to provide guidance to people or groups who have already been serving sentences for carrying out radical actions in the family, then detecting various community activities that lead to radical understanding, provide counseling with religious and community leaders. The obstacles of Deli Serdang Resort Police Intelligence Unit in preventing radical understanding through deradicalization being are the lack of budget for detecting and counseling among the community.

Key-words : Intelligence Unit, Radical Understanding, Public

\section{Abstrak}

Wilayah Hukum Polres Deli Serdang saat ini telah melakukan perannya dalam upaya muncul dan berkembangnya paham radikal kepada masyarakat dengan melibatkan seluruh komponen, serta melakukan deradikalisasi terhadap kelompok atau orang yang sudah pernah melakukan tindakan radikal/teroris sehingga kelompok atau orang tersebut menyadari akan kesalahan dan kelalaiannya atas tindakan yang dapat merugikan keutuhan berbangsa dan bernegara, selain hal tersebut, Polres Deli Serdang juga melakukan berbagai program deradikalisasi.

Adapun permasalahan yang dirumuskan dalam rumusan masalah adalah Bagaimana peran Satuan Intelkam Polres Deli Serdang dalam mencegah paham radikal melalui deradikalisasi. Apa saja upaya yang dilakukan Satuan Intelkam Polres Deli Serdang dalam mencegah paham radikal melalui deradikalisasi.Apakah ada hambatan Satuan Intelkam Polres Deli Serdang dalam mencegah paham radikal melalui deradikalisasi. Metode pendekatan yang dilakukan adalah dengan menggunakan metode yuridis normatif. Metode pendekatan yuridis normatif di pergunakan untuk meneliti bahan pustaka yang merupakan 
Media Komunikasi dan Informasi Hukum dan Masyarakat

data primer. Berdasarkan data yang diperoleh selanjutnya dianalisa untuk diambil kesimpulan setelah diuraikan secara terperinci berdasarkan sumber yang ada.

Adapun hsil penelitian ini adalah Peran Satuan Intelkam Polres Deli Serdang dalam mencegah paham radikal melalui deradikalisasi cukup berperan. Peran yang dilakukan oleh Satuan Intelkam Polres Deli Serdang adalah memonitor terhadap pergerakan masyarakat dan kelompok masyarakat yang agar tidak mengikuti paham radikal, memberikan penyuluhan, melakukan kegiatan bersama kemasyarakatan dan keagamaan. Upaya yang dilakukan Satuan Intelkam Polres Deli Serdang dalam mencegah paham radikal melalui deradikalisasi adalah dengan melakukan pembinaan terhadap orang atau kelompok yang sudah menjalani hukuman karena melakukan tindakan radikal di dalam keluarga. Mendeteksi berbagai kegiatan masyarakat yang mengarah kepada paham radikal, memberikan penyuluhan dengan tokoh agama dan tokoh masyarakat. Adapun hambatan Satuan Intelkam Polres Deli Serdang dalam mencegah paham radikal melalui deradikalisasi antara lain adalah minimnya anggaran yang dimiliki untuk melakukan deteksi dan penyuluhan di tengah-tengah masyarakat.

Kata Kunci : Satuan Intelkam, Paham Radikal, Masyarakat

\section{PENDAHULUAN}

\section{A. Latar Belakang Masalah}

Indonesia dikenal sebagai negara pluralis di mana kemajemukan hadir dan berkembang di dalamnya. Kemajemukan negara Indonesia dapat dilihat dari berbagai macam, suku, ras, budaya, bahkan agama tumbuh di dalamnya. Kemajemukan itu memberikan nilai plus tersendiri bagi negara Indonesia. Namun di sisi lain kemajemukan itu telah membawa akibat yaitu adanya perjumpaan yang semakin intensif antar kelompok-kelompok manusia. Salah satunya adalah pergesekan yang seringkali terjadi di antara agama-agama yang berbeda, bahkan antar internal agama itu sendiri.
Ketika memfokuskan pada agama, maka sesungguhnya ada fenomena yang menarik dalam hubungan antar umat beragama di Indonesia. Fenomena menarik karena sebagian besar masyarakat Indonesia senantiasa mengkondisikan dirinya dalam hubungan mayoritas-minoritas, apalagi ketika hal itu dikaitkan dengan urusan agama. Hal itu sudah terbukti dalam sejarah perjalanan bangsa yang panjang serta pengalamanpengalaman konkrit yang hadir dalam realitas masyarakat Indonesia. Realitas itu nampak kembali melalui peristiwa-peristiwa kemanusiaan yang kini tengah dihadapi oleh seluruh lapisan masyarakat Indonesia.

Radikalisme, anarkisme atau kekerasan bernuansa agama cenderung terus meningkat atau setidaknya timbul tenggelam dalam beberapa tahun belakangan ini. Radikalisme yang memunculkan konflik dan kekerasan sosial bernuansa dan berlatarkan agama terus merebak. Meningkatnya radikalisme dalam agama di Indonesia cenderung disandarkan pada faham keagamaan (khususnya Islam), sekalipun sumbu radikalisme bisa lahir dari mana saja seperti ekonomi, politik, sosial dan lain sebagainya.

Radikalisme yang berujung pada terorisme menjadi masalah penting khususnya bagi umat Islam hari ini. Berbagai aksi teror dan pengeboman telah menyebabkan Islam dicap sebagai agama yang menyukai jalan kekerasan yang dianggap "suci" untuk menyebarkannya. Sekalipun hal ini dapat dengan mudah dimentahkan, namun fakta bahwa pelaku teror adalah seorang muslim garis keras sangat membebani psikologi umat Islam hari ini. Oleh karenanya, peran berbagai pihak dalam mengatasai berkembangnya 
Media Komunikasi dan Informasi Hukum dan Masyarakat

faham radikal di Indonesia khususnya Polri sangat diharapkan.

Polri merupakan institusi pemerintah yang mempunyai tugas pokok penegakkan hukum, memelihara kamtibmas serta meberikan perlindungan, pengayoman dan pelayanan kepada masyarakat. Dalam melaksanakan tugas pokok tersebut maka dalam institusi Polri diperlukan fungsi-fungsi kepolisian yang mempunyai wilayah kerja masing-masing yang saling terkait dan terpadu. Fungsi kepolisian tersebut salah satunya adalah Intelijen keamanan atau yang biasa disebut intelkam. Fungsi ini merupakan salah satu fungsi kepolisian. Kata intelijen berasal dari bahasa Inggris "Intelligence" yang secara harfiah berarti kecerdasan. Secara khusus yang berkaitan dengan upaya mengamankan Negara dan Bangsa"1.

Satuan Intelkam di singkat Sat Intelkam adalah unsur pembantu pimpinan dan pelaksana staf polres yang berada dibawah Kapolresta. Sat Intelkam dipimpin oleh Kepala Satuan Intelkam disingkat Kasat Intelkam yang bertanggungjawab kepada Polresta dan dalam pelaksanaan tugas sehari-hari dibawah kendali Waka Polresta. Tugasnya adalah menyelenggarakan pengawasan / pengamanan kegiatan sosial/politik, masyarakat, Kasat Intelkam dibantu oleh Kaur Binops dan Kanit yang hasil dan pelaksanaannya dikoordinasikan kepada Waka Polresta" 2

Berdasarkan pengertian di atas
dipahami bahwa Intelijen keamanan

${ }^{1}$ WJS. Poerwaadarminta, Kamus Umum Bahasa Indonesia, (Jakarta : Bumi Aksara, 2009), h. 362

2 I Gde Arya Wibawa, Sambangi Tokoh Agama Cegah Radikalisme, (Bali : Sat Intelkam Denpasar, 2017) merupakan bagian integral dari fungsi organik Polri yang menyelenggarakan kegiatan dan operasi Intelijen baik berupa penyelidikan, pengamanan maupun penggalangan dalam bidang keamanan bagi kepentingan pelaksanaan tugas operasional dan manajemen Polri dalam rangka mewujudkan keamanan dalam negeri. Fungsi intelkam merupakan fungsi intelkam yang bertugas Sebagai Mata dan Telinga kesatuan Polri yang berkewajiban melaksanakn deteksi dini dan memberikan peringatan masalah dan perkembangan masalah dan perubahan kehidupan sosial dalam masyarakat, dan juga bertugas mengidentifikasi ancaman, gangguan, atau hambatan terhadap Kamtibmas.

Situasi kamtibmas dan tindak kriminalitas memiliki kecendrungan meningkat dari tahun ke tahun seirama dengan perkembangan berbagai aspek kehidupan masyarakat, sementara itu situasi keamanan dan ketertiban yang kondusif di wilayah adalah mutlak, untuk mewujudkan guna mendukung terselenggaranya pembangunan daerah sampai ke tingkat nasional termasuk berjalannya roda pemerintahan dan perekonomian bangsa.

Fungsi Intelkam sebagai pelaksana fungsi intelijen keamanan yang meliputi penyelidikan, pengamanan dan penggalangan guna terpeliharanya stabilitas keamanan dan ketertiban masyarakat yang kondusif, harus dapat mengantisipasi berbagai perkembangan situasi sehingga apabila muncul ancaman faktual dapat ditangani secara prfesional dan proporsional sesuai dengan prosedur yang ditetapkan dalam peraturan perundangundangan. Fungsi intelkam polri sangat berperan dalam memberikan masukan kepada 
Media Komunikasi dan Informasi Hukum dan Masyarakat

pimpinan tentang perkembangan keamanan dan ketertiban dalam masyarakat.

Lembaga intelijen harus menjaikan lembaga yang tajam dan akurat sehingga segala kemungkinan tentang perkembangan kamtibmas dapat diantisipasi oleh kepolisian. Maka dituntut peran dan fungsi intelkam dalam menjalankan tugasnya dalam menghadapi perkembangan paradigma kamtibmas yang terjadi di wilayah tugasnya masing-masing. Dalam aplikasi sistem pemerintah Indonesia peranan intelijen adalah memberikan peringatan (early detection and early warning system) tentang hal-hal yang berkaitan dengan ancaman terhadap negara dari dalam maupun dari luar. Secara yuridis maka peran intelijen jika diterjemahkan dari tujuan Intelijen Negara yang tertulis dalam UU Nomor 17 tahun 2011 tentang Intelijen Negara Pasal 5 disebutkan bahwa: Tujuan Intelijen Negara adalah mendeteksi, mengidentifikasi, menilai, menganalisis, menafsirkan, dan menyajikan Intelijen dalam rangka memberikan peringatan dini untuk mengantisipasi berbagai kemungkinan bentuk dan sifat ancaman yang potensial dan nyata terhadap keselamatan dan eksistensi bangsa dan negara serta peluang yang ada bagi kepentingan dan keamanan nasional. $^{3}$

Sesuai dengan fenomena yang terjadi di tengah-tengah masyarakat di seluruh wilayah Indonesia bahwa Satuan Intelkam telah banyak berperan dalam menjalankan tugas dan fungsinya terutama dalam pengawasan terhadap kelompok yang melakukan tindakan radikal. Radikal adalah suatu ideologi (ide atau gagasan) dan paham yang ingin melakukan perubahan pada sistem

\footnotetext{
${ }^{3}$ UU Nomor 17 tahun 2011 tentang Intelijen Negara Pasal 5
}

sosial dan politik dengan menggunakan caracara kekerasan/ekstrim." ${ }^{4}$

Inti dari tindakan radikalisme adalah sikap dan tindakan seseorang atau kelompok tertentu yang menggunakan cara-cara kekerasan dalam mengusung perubahan yang diinginkan. Kelompok radikal umumnya menginginkan perubahan tersebut dalam tempo singkat dan secara drastis serta bertentangan dengan sistem sosial yang berlaku. Radikalisme sering dikaitkan dengan terorisme karena kelompok radikal dapat melakukan cara apapun agar keinginannya tercapai, termasuk meneror pihak yang tidak sepaham dengan mereka. Walaupun banyak yang mengaitkan radikalisme dengan Agama tertentu, pada dasarnya radikalisme adalah masalah politik dan bukan ajaran Agama.

Indonesia dewasa ini dihadapkan dengan persoalan dan ancaman radikalisme/terorisme dan separatisme yang kesemuanya bertentangan dengan nilai-nilai Pancasila dan UUD 1945. Raadikalisme merupakan ancaman terhadap ketahanan ideologi. Apabila ideologi negara sudah tidak kokoh maka akan berdampak terhadap ketahanan nasional. Radikalisme dapat diartikan sebagai sikap atau paham yang secara ekstrim.revolusioner dan militan untuk memperjuangkan perubahan dari arus utama yang dianut masyarakat. Radikalisme tidak harus muncul dalam wujud yang berbau kekerasan fisik.ideologi pemikiran, kampanye yang masih dan demonstrasi sikap yang berlawanan dan ingin mengubah mainstream dapat digolongkan sebagai sikap radikal. Melalui peristiwa-peristiwa kemanusiaan yang kini tengah dihadapi oleh seluruh lapisan

\footnotetext{
${ }^{4}$ Zaenal Arifin, Meluruskan Pengertian Radikal. (Jakarta : Kencana, 2013), h.19
} 
Media Komunikasi dan Informasi Hukum dan Masyarakat

masyarakat Indonesia. Meningkatnya radikalisme dalam agama di Indonesia menjadi fenomena sekaligus bukti nyata yang tidak bisa begitu saja diabaikan ataupun dihilangkan. Radikalisme keagamaan yang semakin meningkat di Indonesia ini ditandai dengan berbagai aksi kekerasan dan teror.

Patut dibanggakan bahwa kesemua kejadian yang berkaitan dengan radikal di Indonesia dapat dipantau, diawasi oleh kepolisian terutama Intelkam sesuai tugas dan fungsinya memantau dan mengawasi kehidupan sosial di tengah-tengah masyarakat sekaligus berperan dalam mengayomi dan mengembalikan peran sosial masyarakat secara pribadi maupun kelompok secara normal terutama bagi mereka yang sudah sempat mengikuti gerakan radikal. Satuan Intelkam sangat berperan dalam menormalkan kembali kehidupan orang yang terlanjur memiliki pemahaman yang keliru terhadap ideology bangsa dan Negara Indonesia, hal ini disebut dengan deradikalisasi.

Deradikalisasi adalah tindakan preventif kontraterorisme atau stratregi untuk menetralisir paham-paham yang dianggap radikal dan membahayakan dengan cara pendekatan tanpa kekerasan. Tujuan dari deradikalisasi ini adalah untuk mengembalikan para aktor terlibat yang memiliki pemahaman radikal untuk kembali kejalan pemikiran yang lebih moderat" ${ }^{5}$

Tujuan deradikalisasi tersebut merupakan pemutusan (Disengagment)

${ }^{5}$ Pusbangdatin. "Detailpost - Program

Deradikalisasi sebagai upaya Pencegahan

Terjadinya Tindakan Terorisme di Indonesia". Badan Penelitian dan Pengembangan Hukum dan HAM I Kementerian Hukum dan HAM Republik Indonesia (dalam bahasa Inggris). Diakses tanggal 2018 dimana pemutusan bisa berarti mendorong kelompok radikal untuk meorientasi diri melalui perubahan sosial kognitif sehingga mereka meninggalkan pemahaman radikal yang mereka anut sebelumnya, menuju norma yang baru dalam artian menuju kembali kepemikiran yang tidak radikal. ${ }^{6}$

Jelaslah bahwa tujuan deradikalisasi adalah untuk menormalkan kembali kehidupan dan paham pelaku radikal terhadap pemikiran yang sesuai dengan kaidah pancasila dan UUD 1945 sebagai dasar Negara Republik Indonesia sehingga terjadi reorientasi pemikiran dalam kehidupan sosial. Dalam mengatasi permasalahan tersebut, pemerintah juga melakukan pendekatan terhadap narapidana terorisme dilapas melalui rehabilitasi baik itu dengan pendekatan karakter kebangsaan dan menanamkan nilainilai perdamaian, serta peran aktif ormas keagamaan dalam mempromosikan nilai-nilai pluralisme seperti yang dilakukan oleh Nahdlatul Ulama dan Muhammadiyah. Sasaran utama dari sosialisasi deradikalisasi adalah tahanan ataupun mantan teroris serta sangat diperlukan dan dibutuhkan dukungan dari berbagai pemangku kekuasaan, lebih lagi sosialisasi deradikalisasi juga perlu diperuntukan kepada komunitas-komunitas masyarakat yang potensial di masuki paham radikal".7

Berbagai program yang dilakukan oleh pemerintah dan kelompok masyarakat dalam meradikalisasi orang atau kelompok yang pernah melakukan tindakan radikal, terorisme

\footnotetext{
${ }^{6}$ Petrus Colose, Deradikalisasi di Indonesia, (Jakarta : Asia Report, 2007), h.8 ${ }^{7}$ A.S., Hikam, Muhammad, Deradikalisasi : Peran Masyarakat Sipil Indonesia Membendung Radikalisme. (Jakarta: Penerbit Buku Kompas, 2016), h. 132
} 
Media Komunikasi dan Informasi Hukum dan Masyarakat

dan berbagai aktivitas yang dapat mengancam keutuhan berbangsa dan bernegara. Kesemua itu dilakukan dengan bekerjasama melalui seluruh komponen masyarakat terutama TNI dan Polri.

\begin{tabular}{ccc}
\multicolumn{3}{r}{ Berdasarkan kajian terdahulu Peran } \\
Intelkam Polda Lampung Dalam
\end{tabular}
Mengidentifikasi Ancaman Terhadap Gangguan Kamtibmas (Tesis) Oleh Nugraha Aditama Ramadhan 2017 bahwa Peran Intelkam Polda Lampung dalam mengidentifikasi ancaman terhadap gangguan kamtibmas termasuk dalam peran normatif dan faktual. Peran normatif dilaksanakan berdasarkan peraturan Undang-Undang Nomor 2 Tahun 2002 tentang Kepolisian sesuai dengan tugas pokok, fungsi dan wewenang yang dimilikinya. Peran faktual dilaksanakan dengan kegiatan pengumpulan bahan/data, pembuatan hipotesa, pengumpulan data tambahan, analisis dan konklusi data intelijen dalam kasus aksi massa ormas Tim Andalan Masyarakat Pasukan Inti Lampung (Tampil) dengan sekelompok massa salah satu ormas di Lampung di Kantor Dinas Kesehatan Provinsi Lampung yang berpotensi menyebabkan gangguan kamtibmas

Penelitian terdahulu tersebut menunjukkan bahwa Intelkam berfungsi dalam upaya pengamanan terhadap ancaman keamanan Negara baik berupa idealism maupun idologi. Kabupaten Deli Serdang sebagai salah satu Kabupaten di Indonesia memiliki wilayah yang sangat luas dan berpotensi terjadinya berbagai tindakan radikal, melihat suku, agama dan ras yang berbeda. Bahkan berdasarkan keterangan Kapolres Deli Serdang bahwa Kapolres Deli Serdang AKP Robert Da Costa mengatakan, ada beberapa wilayah yang terkontaminasi paham radikal di wilayah hukumnya. Ada kelompok kecil dan perorangan yang teridentifikasi terpapar radikalisme di wilayah yang tidak disebut namanya itu. "Potensi radikalisme di wilayah Deli Serdang cukup banyaka, ada yang berkelompok, ada yang individu. ${ }^{8}$

Mengatasai persoalan ini Polres Deli Serdang melakukan pengawasan dan pengamanan yang maksimal karena tidak mau lagi terulang dengan kasus setelah tim Densus 88 menangkap seorang terduga teroris Syafii di Desa Ajibaho, Kecamatan Biru biru, Kabupaten Deli Serdang. Dari hasil pemeriksaan Polri, Syafii merupakan pelaku perseorangan yang terafiliasi Jaringan Ansharut Daulah (JAD)"9.

Tertangkapnya Syafii sebagai salah satu anggota teroris menunjukkan bahwa Kabupaten Deli Serdang telah mengalami dan menghadapi kelompok radikalisme berupa terorisme. Dalam mempertahankan keamanan masyarakat sekaligus membendung muncul dan berkembangnya radikalisme, Kapolda beserta Polresta Deli Serdang melakukan upaya radikalisasi dengan berbagai kegiatan, salah satunya adalah bahwa Kapolda Sumatera Utara (Sumut) Irjen Pol Agus Andrianto secara resmi mendirikan galeri perdamaian di Pondok Pesantren (Ponpes) AlHidayah yang berada di Desa Sei Mencirim, Kecamatan Kutalimbaru, Deli Serdang. Dalam acara ini dihadiri oleh oleh sejumlah pejabat utama Polda Sumut, Wakapolda Sumut, Brigjen Pol Mardiaz Kusin, Kapolrestabes Medan, Kombes Pol Dadang Hartanto, Dirkrimum Kombes Andi Rian, Dir Intelkam, Kombes Dedy Kusuma Bakti, Kabid Humas,

${ }^{8}$ Robert Da Costa, Tiga Wilayah di Deli Serdang Terkontaminasi Radikalisme, (Jakarta, Netralnews.Com, Penulis, Juven Martua Sitompul, Rabu, 20 Sep 2017 ) ${ }^{9} \mathrm{lbid}$. 
Media Komunikasi dan Informasi Hukum dan Masyarakat

Kombes Pol Tatan Dirsan Atmaja. Peresmien ini bertujuan untuk "mengingatkan kembali generasi muda dan masyarakat akan bahaya paham radikal dan teroris. Agar semua masyarakat sadar, Indonesia ini perlu dijaga dengan kedamaian"10

Selain itu Polres Deli Serdang menerima kunjungan Tim dari Div Humas Mabes Polri, Bertempat di Aula Tribrata Polres Deli Serdang. Adapun Tujuan Kedatangan Tim Dari Div Humas Polri yang dipimpin oleh Kombes Pol Drs. Syahardi Antono, M.Si ke Polres Deli Serdang yakni melaksanakan Liputan Kontra Radikal dan Publikasi Kinerja Polres Deli Serdang dalam mencegah Berkembangnya Paham Radikal Di Wilayah Hukum Polres Deli Serdang. Acara Peliputan Dan Publikasi ini sendiri dihadiri oleh Seluruh Elemen Masyarakat kab. Deli Serdang diantaranya ialah tokoh masyarakat, tokoh adat, tokoh agama, mahasiswa Kabupaten Deli serdang dan Para Insan Pers. Acara dilanjutkan dengan Pernyataan Deklarasi Dukungan Pemilu 2019 yang aman, damai dan sejuk serta menolak segala bentuk ujaran kebencian, hoax dan radikalisme oleh Kapolres Deli Serdang beserta para peserta hadirin yang terdiri dari berbagai elemen Masyarakat Kabupaten Deli Serdang"11

Sesuai dengan latar belakang masalah di atas, menunjukkan bahwa Wilayah Hukum Polres Deli Serdang saat ini telah melakukan perannya dalam upaya muncul dan berkembangnya paham radikal kepada masyarakat dengan melibatkan seluruh

${ }^{10}$ Agus Andrianto, Cegah Faham Radikalisme Polda Sumut Resmikan Galeri Perdamaian, (Polda Sumut, Medan Hedlines Com, 01-01-2018)

${ }^{11}$ Media Dunia News, Co, Polres Deli Serdang terima Kunjungan Tim dari Div Humas Mabes Polri, Deli Serdang, 2018 komponen, serta melakukan deradikalisasi terhadap kelompok atau orang yang sudah pernah melakukan tindakan radikal/teroris sehingga kelompok atau orang tersebut menyadari akan kesalahan dan kelalaiannya atas tindakan yang dapat merugikan keutuhan berbangsa dan bernegara, selain hal tersebut, Polres Deli Serdang juga melakukan berbagai program deradikalisasi secara rutin dan berkesinambungan yang nantinya dapat dipaparkan dalam pembahasan tesis ini.

Adapun kasus yang sudah dilakukan penangkapan oleh Polres Deli Serdang bekerjasama dengan militer adalah tanggal 10 Jan 2017, Penangkapan Jaringan Terorisme Di Pelabuhan Batam, tanggal 06 Jun 2017, Penangkapan Jaringan Terorisme Di Medan, tanggal 15 mei 2018, penggerebekan terorisme di Tanjung Balai. Sementara tindakan hukum yang sudah dilakukan adalah menahan Saidih Fitriana Alias Adi alias Ceking Alias Memet alias Donialamsyah di Lapas Tanjung Gusta, Cunaedi bin Sudarba, Dadang Syarifuddin.

Sementara tindakan deradikalisasi yang dilakukan saat ini oleh pihak Polres Deli Serdang adalah Deradikalisasi terhadap Napiter, eks napiter dan kelompok radikal, melakukan pengawasan terhadap aliran agama, tokoh agama dan orangtua agar tidak terkontaminasi dengan radikalisme, penerapan hukum tegas terhadap Apkum dan ormas.

\section{B. Rumusan Masalah}

Berdasarkan latar belakang masalah yang telah dijabarkan, maka penulis merumuskan rumusan masalah : Bagaimana peran Satuan Intelkam Polres Deli Serdang dalam mencegah paham radikal melalui deradikalisasi 
Media Komunikasi dan Informasi Hukum dan Masyarakat

\section{Tujuan Penelitian}

Berdasarkan rumusan masalah yang telah dirumuskan maka tujuan dari penelitian ini adalah :

1. Untuk mengetahui peran Satuan Intelkam Polres Deli Serdang dalam mencegah paham radikal melalui deradikalisasi

2. Untuk mengetahui hambatan Satuan Intelkam Polres Deli Serdang dalam mencegah paham radikal melalui deradikalisasi

3. Untuk mengetahui upaya yang dilakukan Satuan Intelkam Polres Deli Serdang dalam mencegah paham radikal melalui deradikalisasi

\section{Manfaat Penelitian}

Penelitian ini dilakukan dengan harapan dapat bermanfaat :

1. Manfaat Teoritis

Penelitian ini agar dapat bermanfaat bagi perkembangan ilmu hukum pada umumnya dan perkembangan bidang hukum pidana pada khususnya yaitu berkaitan dengan peran intelkam dalam mengatasi paham radikal melalui deradikalisasi.

2. Manfaat Praktis

Penelitian ini diharapkan bermanfaat bagi pihak-pihak terkait yaitu:

a. Untuk pemerintah, agar lebih memperhatikan dan memperkuat nasionalisme bagi masyarakat.

b. Bagi Polri khususnya dapat menjadi dasar pemikiran untuk melakukan langkah-langkah strategis dalam mencegah paham radikal

c. Untuk orangtua, agar dapat memberikan pandangan dan pendidikan agama supaya tidak terpengaruh dengan paham radikal d. Untuk masyarakat, agar tokoh agama dan tokoh masyarakat dapat lebih waspada terhadap kelompok atau orang yang mencoba menyebarkan paham radikal.

\section{E. Keaslian Penelitian}

Keaslian penelitian dimaksudkan bahwa penelitian yang penulis lakukan dinyatakan asli dan tidak kesamaan dengan penelitian orang lain. Namun penelitian ini memiliki relevansi dengan beberapa penelitian seperti :

1. Penelitian Nugraha Aditama Ramadhan 2017, Peran Intelkam Polda Lampung Dalam Mengidentifikasi Ancaman Terhadap Gangguan Kamtibmas. Peran Intelkam Polda Lampung dalam mengidentifikasi ancaman terhadap gangguan kamtibmas termasuk dalam peran normatif dan faktual.

2. Arham Gusdiar, 2012, Peran Intelijen Keamanan Dalam Melakukan Deteksi Dini Terhadap Perkembangan Gangguan Kamtibmas. Penelitian ini menggambarkan Intelkam Polri sangat berperan penting dalam meberikan diteksi dini terutama dalam mengantisipasi gangguan kamtibmas yang dapat terjadi kapanpun yang tidak mengenal waktu dan tampat.

\section{F. Kerangka Teori dan Kerangka Konsep}

1. Kerangka Teori

\section{a.Tinjauan Umum Peran Intelkam}

Kerangka teoritis adalah abstraksi hasil pemikiran atau kerangka acuan atau dasar yang relevan untuk pelaksanaan suatu penelitian ilmiah, khususnya penelitian hukum. Berdasarkan definisi tersebut maka kerangka 
Media Komunikasi dan Informasi Hukum dan Masyarakat

teoritis yang digunakan dalam penelitian ini adalah peran.

Peran adalah aspek dinamis kedudukan (status), yang memiliki aspek-aspek sebagai berikut:

a. Peran meliputi norma-norma yang dihubungkan dengan posisi atau tempat seseorang dalam masyarakat. Peran dalam arti ini merupakan rangkaian peraturan yang membimbing seseorang dalam kehidupan masyarakat.

b. Peran adalah suatu konsep perihal apa yang dapat dilakukan oleh individu dalam masyarakat sebagai organisasi.

c. Peran juga dapat diartikan sebagai perilaku individu yang penting bagi struktur sosial masyarakat. ${ }^{12}$

Secara umum peran adalah suatu

keadaan di mana seseorang melaksanakan

hak dan kewajibannya dalam suatu sistem atau organisasi. Kewajiban yang dimaksud dapat berupa tugas dan wewenang yang diberikan kepada seseorang yang memangku jabatan dalam organisasi ${ }^{13}$.

Selanjutnya peran terbagi menjadi :

a. Peran normatif adalah peranyang dilakukan oleh seseorang atau lembaga yang didasarkan pada seperangkat norma yang berlaku dalam kehidupan masyarakat.

b. Peran ideal adalah peranyang dilakukan oleh seseorang atau lembaga yang didasarkan pada nilai-nilai ideal atau yang seharusnya dilakukan sesuai dengan kedudukannya di dalam suatu sistem.

c. Peran faktual adalah peranyang dilakukan oleh seseorang atau lembaga yang didasarkan pada kenyataan secara kongkrit di lapangan atau kehidupan sosial yang terjadi secara nyata. ${ }^{14}$

Berdasarkan definisi tersebut, maka batasan pengertian dari istilah yang digunakan dalam penelitian ini adalah sebagai berikut:

${ }^{12}$ Soerjono Soekanto, Pengantar Penelitian Hukum,(Jakarta Rineka Cipta, 2006), h.103

${ }^{13}$ Soerjono Soekanto., Sosiologi Suatu Pengantar, (Jakarta : Rajawali Pers, 2002), h.24

14 Ibid. h.32 a. Peran adalah aspek dinamis kedudukan (status). Apabila seseorang melaksanakan hak dan kewajibannya sesuai dengan kedudukannya maka dia menjalankan suatu peran

b. Intelijen Kepolisian adalah serangkaian usaha, kegiatan, pekerjaan yang diwujudkan dalam bentuk-bentuk kegiatan penyelidikan, Pengamanan dan penggalangan untuk keperluan pelaksanaan tugas pokok kepolisian yang meliputi pemeliharaan keamanan masyarakat, penegakan hukum, perlindungan, pengayoman dan pelayanan masyarakat. ${ }^{15}$

Sesuai dengan pengertian di atas, maka yang dimaksudkan dalam penelitian ini adalah peran intekam polisi dalam menjalankan tugas dan fungsinya sebagai pelaksana keamanan masyarakat, perlindungan dan pelayanan.

\section{b. Pengertian Satuan Intelkam}

Intelkam POLRI adalah sebagai Mata

dan Telinga kesatuan POLRI yang berkewajiban melaksanakan deteksi dini dan memberikan peringatan masalah dan perkembangan masalah dan perubahan kehidupan sosial dalam masyarakat. Serta dapat mengidentifikasi ancaman, gangguan, atau hambatan terhadap Kamtibmas (Keamanan dan ketertiban masyarakat. ${ }^{16}$

Hal ini menandakan bahwa Intelkam merupakan basis terdepan POLRI dalam hal mengayomi masyarakat dan menangkal segala sesuatu yang dapat mengganggu ketertiban dan keamanan. Ditintelkam mempunyai tugas dan fungsi yang diatur dalam Peraturan Kepala Kepolisian Republik Indonesia (Perkap) No. 22 Tahun 2010 tentang Susunan Organisasi dan Tata Kerja pada Tingkat Kepolisian Daerah.

${ }^{15}$ Saronto, Y.Wahyu, Intelijen, Teori dan Aplikasi dan Modernisasi, (Jakarta : Ekalaya Saputra, 2001), h.12

"16 Rusman Hadi, Polri Menuju

Reformasi, (Jakarta : Yayasan Tenaga Kerja, Baintelkam POLRI, 2012), h.35 
Media Komunikasi dan Informasi Hukum dan Masyarakat

Intelkam adalah kepanjangan dari intelijen keamanan, dimana kalimat intelijen sudah tidak asing lagi bagi kita.

Istilah intelijen dikalangan masyarakat sering dikaitkan dengan kerahasiaan, "clock and dagger" (matel panjang dan belati), bahkan sering disamakan dengan spionage yang serba tertutup. Terdapat pula berbagai istilah tentang intelijen, seperti "intelijen dalam negeri”, “intelijen luar negeri”, “intelijen militer dalam negeri", "intelijen strategis", "combat intelligence" "police intelligence", "criminal intelligence", "intelijen bisnis", dan sebagainya. ${ }^{17}$

Menurut Supono Soegirman bahwa pengertian intelijen sebagai organisasi adalah "struktur formal dalam sebuah negara sebagai wadah sejumlah sumber daya manusia yang memiliki keahlian dan ketrampilan khusus dengan karakteristik khusus yang secara umum bersifat tertutup, bertujuan mengamankan kepentingan nasional"18

Satuan Intelkam adalah unsur pelaksana utama Polres bertugas menyelenggarakan/membina fungsi Intelejen bidang Keamanan, termasuk persandian, dan pemberi pelayanan dalam bentuk Surat izin / Keterangan yang menyangkut Orang Asing, Senjata Api \& Bahan Peledak, kegiatan social / Politik masyarakat dan Surat Keterangan Catatan Kepolisian (SKCK) kepada warga masyarakat yang membutuhkan serta

17 WJS. Poerwadarminta, Kamus Umum Bahasa Indonesia, (Jakarta : Balai Pustaka, 2006), h.154

18 Soepomo Soegirman, Inteligen Profesi Untuk Orang-orang Aneh, (Jakarta : Bumi Aksara, 2011), h.10 melakukan pengawasan / pengamanan dan pelaksanaannya."19

Dalam UU Republik Indonesia No.17 Tahun 2011 tentang Intelijen negara, dinyatakan intelijen dapat berarti :

1. Intelijen adalah pengetahuan, organisasi, dan kegiatan yang terkait dengan perumusan kebijakan, strategi nasional, dan pengambilan keputusan berdasarkan analisis dari informasi dan fakta yang terkumpul melalui metode kerja untuk pendeteksian dan peringatan dini dalam rangka pencegahan, penangkalan, dan penanggulangan setiap ancaman terhadap keamanan nasional.

2. Intelijen Negara adalah penyelenggara Intelijen yang merupakan bagian integral dari sistem keamanan nasional yang memiliki wewenang untuk menyelenggarakan fungsi dan kegiatan Intelijen Negara. ${ }^{20}$

Rumusan-rumusan tersebut diatas merupakan intelijen terbuka yang dilakukan oleh semua organisasi intelijen. Dalam praktek, masih banyak pula dilakukan intelijen tertutup, bahkan intelijen yang sebenarnya melanggar hukum (clandestine intelligence operation), terutama antar negara yang bermusuhan. Organisasi pada kepolisian, intelijen tidak bisa dihapus, karena merupakan fungsi organik, yang beda dengan angkatan perang. Intelijen Kepolisian atau police intelligence mencakup "criminal intelligence", yang merupakan bagian integral dari fungsi utama Polri, yaitu represif, preventif, dan pembinaan masyarakat (yang akhir akhir ini kemudian sering disebut preemptif)." 21

19 Priyo Widyanto, Tugas Pokok dan Fungsi Intelkam, (Balikpapan : Kapolres Balikpapan, 2012)

20 UU Republik Indonesia No.17 Tahun 2011 tentang Intelijen Negara, Bab I Pasal 1 ayat (1) dan (2)

${ }^{21}$ Cahya Suryana, Tugas Pokok dan Fungsi Intelijen Keamanan (Satintelkam),(Sebuah Artikel, 2012). 
Media Komunikasi dan Informasi Hukum dan Masyarakat

Dasar hukum tugas pelaksanaan intelkam sesuai dengan Pasal 30 Ayat (4) UUD 1945 yang menyebutkan "Kepolisian Negara Republik Indonesia sebagai alat negara yang menjaga keamanan dan ketertiban masyarakat bertugas melindungi, mengayomi, melayani masyarakat serta menegakkan hukum". Maka dengan demikian, fungsi intelijen di Polri bukanlah hanya intelijen kriminalitas, namun ada beberapa fungsi intelijen lainnya yang belum dikembangkan. dengan sasaran tugas dan jenis intelijen yang digunakan"22

Berdasarkan pengertian di atas, maka dapat dipahami bahwa Intelijen dalam pengertiannya sebagai organisasi merupakan badan/alat yang dipergunakan untuk menggerakkan kegiatan-kegiatan intelijen sesuai dengan fungsinya, baik berupa penyelidikan, pengamanan maupun penggalangan untuk mencapai tujuan - tujuan intelijen guna memnuhi kepentingan pihak atasan yang berwenang dan bertanggung jawab. Yang penting untuk diperhatikan dalam penyusunan organisasi intelijen adalah faktor efisiensi, efektifitas dan produktivitas. Intelijen sebagai Organisasi/Badan menyangkut hal hal dasar pengorganisasian dan bentuk organisasi.

\section{c. Tugas dan Fungsi Satuan Intelkam}

$$
\text { Sat Intelkam bertugas }
$$

menyelenggarakan / membina fungsi Intelejen bidang Keamanan, termasuk persandian, dan pemberi pelayanan dalam bentuk Surat izin / Keterangan yang menyangkut Orang Asing, Senjata Api \& Bahan Peledak, kegiatan social/Politik masyarakat dan Surat Keterangan Catatan Kepolisian (SKCK) kepada warga

\footnotetext{
${ }^{22}$ Pasal 30 Ayat (4) Undang-Undang Dasar 1945
}

masyarakat yang membutuhkan serta melakukan pengawasan / pengamanan dan pelaksanaannya.

Sat Intelkam dipimpin oleh Kepala Sat Intelkam, disingkat Kasat Intelkam yang bertanggung jawab kepada Kapolres dan dalam pelaksanaan tugas sehari-hari di bawah kendali Waka Polres. Sat Intelkam terdiri dari Urusan Administrasi dan Ketatausahaan, serta sejumlah Unit diantaranya :

1. Urusan Pembinaan Operasi disingkat Urbin Ops

2. Urusan Sandi bertugas melaksanakan giat Persandian

3. Urusan Yanmin bertugas melaksanakan Pelayanan Administrasi

4. Unit Opsnal :
a) Unit Bidang Sosial Ekonomi
b) Unit Bidang Sosial Budaya
c) Unit Bidang Keamanan
d) Unit Bidang Politik
e) Wasendak (Pengawasan Senjata dan Bahan Peladak)
f) POA (Pengawasan Orang asing)

Adapun yang menjadi tugas pokok Sat Intelkam adalah :

1. Sebagai Mata dan Telinga kesatuan Polri yang berkewajiban melaksanakn deteksi dini dan memberikan peringatan masalah dan perkembangan masalah dan perubahan kehidupan sosial dalam masyarakat. Mengidentifikasi ancaman, gangguan, atau hambatan terhadap Kamtibmas.

2. Melaksanakan pengamatan terhadap sasaran-sasaran tertentu dalam masyarakat di bedang Ipoleksosbudhankam bagi kepentingan yang membahayakan masyarakat khususnya dalam kegiatan kontra Intelijen;

3. Menciptakan kondisi tertentu yang menguntungkan dalam masyarakat bagi pelakasanaan tugas Polri. ${ }^{23}$

Penyelidikan, Pengamanan dan penggalangan untuk keperluan pelaksanaan tugas dan fungsi kepolisian, terutama penegakan hukum, pembinaan kamtibmas,

\footnotetext{
${ }^{23}$ UU Intelijen No.17 Tahun 2011, Tentang Tugas Pokok Intelijen
} 
Media Komunikasi dan Informasi Hukum dan Masyarakat

serta keperluan tugas bantuan pertahanan dan

kekuatan sosial.

Berdasarkan UU Republik Indonesia

No,.17 Tahun 2011 tentang tugas dan peran,

tujuan dan fungsi Intelijen adalah :

\section{Bagian Kesatu Peran}

Pasal 4

Intelijen Negara berperan melakukan upaya, pekerjaan, kegiatan, dan tindakan untuk deteksi dini dan peringatan dini dalam rangka pencegahan, penangkalan, dan penanggulangan terhadap setiap hakikat ancaman yang mungkin timbul dan mengancam kepentingan dan keamanan nasional.

Bagian Kedua Tujuan

Pasal 5

Tujuan Intelijen Negara adalah mendeteksi, mengidentifikasi, menilai, menganalisis, menafsirkan, dan menyajikan Intelijen dalam rangka memberikan peringatan dini untuk mengantisipasi berbagai kemungkinan bentuk dan sifat ancaman yang potensial dan nyata terhadap keselamatan dan eksistensi bangsa dan Negara serta peluang yang ada bagi kepentingan dan keamanan nasional.

Bagian Ketiga Fungsi

Pasal 6

(1) Intelijen Negara menyelenggarakan fungsi penyelidikan, pengamanan, dan penggalangan.

(2) Penyelidikan sebagaimana dimaksud pada ayat (1) terdiri atas serangkaian upaya, pekerjaan, kegiatan, dan tindakan yang dilakukan secara terencana dan terarah untuk mencari, menemukan, mengumpulkan, dan mengolah informasi menjadi Intelijen, serta menyajikannya sebagai bahan masukan untuk perumusan kebijakan dan pengambilan keputusan.

(3) Pengamanan sebagaimana dimaksud pada ayat (1) terdiri atas serangkaian kegiatan yang dilakukan secara terencana dan terarah untuk mencegah dan/atau melawan upaya, pekerjaan, kegiatan Intelijen, dan/atau Pihak Lawan yang merugikan kepentingan dan keamanan nasional.

(4) Penggalangan sebagaimana dimaksud pada ayat (1) terdiri atas serangkaian upaya, pekerjaan, kegiatan, dan tindakan yang dilakukan secara terencana dan terarah untuk memengaruhi Sasaran agar menguntungkan kepentingan dan keamanan nasional.

(5) Dalam menyelenggarakan fungsi sebagaimana dimaksud pada ayat (1), ayat (2), ayat (3), dan ayat (4) harus menghormati hukum, nilai-nilai demokrasi, dan hak asasi manusia. ${ }^{24}$

Salah satu tugas intelkam adalah Sebagai Mata dan Telinga kesatuan Polri yang berkewajiban melaksanakn deteksi dini dan memberikan peringatan masalah dan perkembangan masalah dan perubahan kehidupan sosial dalam masyarakat. Serta dapat mengidentifikasi ancaman, gangguan, atau hambatan terhadap Kamtibmas. Didalam intelkam polri terdapat Sistem deteksi Intelpampol, sistem ini sebagai bagian dari Sistem Operasional Intelpampol dalam rangka mewujudkan kemampuan Intelpampol sebagaimana yang ditetapkan. Pada hakekatnya system deteksi dini ini bertitik tolak dari dasar-dasar pelaksanaan tugas Intelpampol. Dasar-dasar pelaksanaan tugas Intelpampol bermula dari pengertian bahwa Intelejen itu adalah untuk Pimpinan dalam kualifikasinya Sebagai Kepala/Komandan, Sebagai unsur pemerintah, Sebagai Pimpinan masyarakat, Sebagai Bapak dari keluarga besar Polri. Dimana pelaksanaan tugas Intelpampol diselenggarakan oleh jaringan Intelpampol di atas permukaan secara struktural formal dengan didukung oleh adanya jaringan Intelijen di bawah permukaan. Sistem Deteksi Intelpampol dapat dilihat dari subyek penyelenggaranya, metoda yang dipakai serta obyek sasarannya. Deteksi Intelpampol diselenggarakan melalui jaringan Intelpampol

${ }^{24}$ UU Republik Indonesia No.17 Tahun 2011 tentang Intelijen Negara, Bab II Pasal 4,5 dan 6) 
Media Komunikasi dan Informasi Hukum dan Masyarakat

di atas permukaan (jaringan Intelpampol struktural formal) mulai dari tingkat Polsek sampai dengan tingkat Mabes Polri dengan menetapkan Polsek sebagai Basis Deteksi Intelpampol, Polres sebagai Basis Operasional dan Polwil ke atas memberikan Back Up Operasional." 25

Adapun yang menjadi intelijen keamanan yang berkemampuan pengindera dini dan pencegah efektif, setiap gangguan keamanan dalam negeri yang akan merusak sendi kehidupan bermasyarakat, berbangsa dan bernegara dalam NKRI yang berdasarkan Pancasila Dan UUD 1945. Sedangkan Misi Sat Intelkam adalah :

1. Mendeteksi secara dini sumber-sumber potensi gangguan keamanan dalam negeri.

2. Mewujudkan kondisi yang mendukung terselenggaranya giat pemerintahan dan kehidupan masyarakat serta terjaminnya kepentingan nasional.

3. Mewujudkan intelijen keamanan sebagai pusat informasi keamanan yang akurat, aktual dan terpercaya dalam rangka mengamankan kehidupan bermasyarakat, berbangsa dan bernegara.

4. Membangun intelijen keamanan beserta infra strukturnya dalam satu sistem terintegrasi dan tergelar dari tingkat pusat sampai tingkat kewilayahan yang didukung oleh etika profesi intelijen.

5. Membangun dan mengembangkan kerjasama dengan badan intelijen dalam dan luar negeri sebagai salah satu wujud sinergi upaya pemeliharaan keamanan.

6. Membangun jaringan komunikasi dalam masyarakat sejalan dengan pemberdayaan masyarakat dalam keamanan dan ketertiban masyarak"26

Berdasarkana uraian di atas maka jelaslah bahwa visi dan misi Sat Intelkam adalah melakukan pendeteksian, pengawasan, dan pemeliharaan keamanan dan ketertiban masyarakat.

\footnotetext{
25 Ibid.

${ }^{26}$ Stainislaus Riyatna, Kajian Stratejik Intelijen, (Jakarta UI:Jurnallnelijen, 2015)
}

Badan intelijen di tubuh Kepolisian didirikan, paska terbentuknya Djawatan Kepolisian Negara (DKN) pada 19 Agustus 1945, yang ditetapkan oleh Panitia Persiapan Kemerdekaan Indonesia (PPKI) serta penetapan RS.Soekanto Tjokrodiatmodjo sebagai Kepala Kepolisian Nasional (KKN), yang berada di bawah kendali Departemen Dalam Negeri. Lahirnya Maklumat $X$ tanggal 3 November 1945 yang membebaskan masyarakat untuk membentuk organisasi dan partai politik, menjadi titik awal keberadaan Badan Intelejen Kepolisian berdiri. Ini disebabkan karena lonjakan aspirasi dan kepentingan masyarakat diasumsikan akan membangun situasi yang tidak kondusif bagi penegakan keamanan dalam negeri sebagai akibat begitu banyaknya partai-partai politik baru maupun organisasi-organisasi masyarakat yang berdiri. Sehingga pada awal tahun 1946, dibentuklah kekuatan intelijen yang mampu mencegah dan mengatasi gangguan keamanan yang disebabkan oleh aktivitas masyarakat tersebut. Fungsi dan peranan lembaga intelejen Kepolisian ini diberi nama Pengawasan Aliran Masyarakat (PAM), pimpinan R.Moch.Oemargatab. Tugas pokok dari PAM ini memang lebih spesifik pada pengawasan aktivitas masyarakat dibandingkan Badan Istimewa $(\mathrm{BI})$ pimpinan Zulkifli Lubis yang lebih mengarah kepada dinamika politik dan pengembangan kontra intelijen terhadap Belanda dan Sekutunya.

Seiring dengan perjalanan waktu, DKN kemudian dikeluarkan dari lingkungan Departemen Dalam Negeri, dengan diterbitkannya Penetapan Pemerintah No. 11/S.D tahun 1946 pada tanggal 1 Juli 1946. Sehingga struktur organisasi DKN langsung di bawah Perdana Menteri. Perubahan ini juga 
Media Komunikasi dan Informasi Hukum dan Masyarakat

berimplikasi pada keberadaan PAM, sebagai satuan intelijen di Kepolisian, yang mengalami pemekaran tugas pokok dari yang sangat umum menjadi lebih khusus. Pada PAM sebelum terbitnya Penetapan Pemerintah No. 11/S.D tahun 1946, tugas pokoknya sebagai berikut: "Mengawasi semua aliran dan memusatkan segala minatnya kepada hajathajat dan tujuan-tujuan dari seseorang atau golongan penduduk yang ada atau timbul di daerah Republik Indonesia atau yang datang dari luar, yang dianggap dapat membahayakan kesentausaan Negara Indonesia dan sebaliknya membantu hajat dan cita-cita seseorang atau golongan penduduk yang bermaksud menyentausakan negara dan keamanan Republik Indonesia serta tugas riset dan analisis lainnya." 27

Pasca reformasi dan pemisahan Polri dari $\mathrm{ABRI}$, struktur Polri direorganisasi melalui UU no. 2 tahun 2002 tentang Kepolisian dan Peraturan Presiden no. 52 tahun 2010. Baintelkam Polri merupakan unsur pelaksana tugas pokok bidang intelijen keamanan yang berada di bawah Kapolri; serta Baintelkam Polri bertugas membantu Kapolri dalam membina dan menyelenggarakan fungsi intelijen keamanan bagi kepentingan pelaksanaan tugas dan manajemen Polri secara umum guna mendukung pelaksanaan tugas-tugas pemerintahan dalam rangka mewujudkan keamanan dalam negeri.

Berdasarkan Instruksi Presiden no. 5 tahun 2002, seluruh kegiatan intelijen di Indonesia dikoordinasikan oleh Badan Intelijen Negara, yang kemudian diperkuat melalui UU no. 17 tahun 2011 tentang Intelijen. Dalam UU tersebut juga diatur bahwa Intelijen Kepolisian

\footnotetext{
${ }^{27}$ Penetapan Pemerintah No. 11/S.D tahun 1946, tugas pokoknya Intelijen.
}

Negara Republik Indonesia merupakan penyelenggara fungsi intelijen kepolisian (Paragraf 3, Pasal 12, Ayat 1) dan merupakan penyelenggara intelijen negara bersama-sama BIN, Intelijen Kejaksaan, Intelijen TNI, serta Intelijen Kementerian/Lembaga. UU tersebut juga mengatur batas-batas dan ketentuanketentuan lebih lanjut mengenai tugas dan fungsi intelijen. ${ }^{28}$

Selain melakukan pekerjaan intelijen, Baintelkam dan Satintelkam juga melayani masyarakat terkait beberapa hal yaitu:

a. Penerimaan pemberitahuan dan pemberian ijin kegiatan masyarakat, (Izin Keramaian)

b. Surat Keterangan Catatan Kepolisian (SKCK),

c. Administrasi pengawasan orang asing; serta

d. Administrasi senjata api dan bahan peledak"29 $^{\prime 29}$

Berdasarkan uraian di atas, maka jelaslah bahwa sat Intelkam memiliki tugas yang tidak hanya di bidang pendeteksian atau pengawasan terhadap keamanan masyarakat, tetapi juga melakukan pelayanan terhadap masyarakat sesuai dengan tugas pokoknya.

Dalam aplikasi sistem pemerintah Indonesia peranan intelijen adalah memberikan peringatan (early detection and early warning system) tentang hal-hal yang berkaitan dengan ancaman terhadap negara dari dalam maupun dari luar. Secara yuridis maka peran intelijen jika diterjemahkan dari tujuan Intelijen Negara yang tertulis dalam UU Nomor 17 tahun 2011 tentang Intelijen Negara Pasal 5 disebutkan bahwa: Tujuan Intelijen Negara adalah mendeteksi, mengidentifikasi, menilai,

\footnotetext{
${ }^{28}$ UU Intelijen No.17 Tahun 2011, dan Instruksi

Presiden No.5 Tahun 2002
29 Ibid
} 
Media Komunikasi dan Informasi Hukum dan Masyarakat

menganalisis, menafsirkan, dan menyajikan Intelijen dalam rangka memberikan peringatan dini untuk mengantisipasi berbagai kemungkinan bentuk dan sifat ancaman yang potensial dan nyata terhadap keselamatan dan eksistensi bangsa dan negara serta peluang yang ada bagi kepentingan dan keamanan nasional. ${ }^{30}$

Secara umum fungsi sebuah organisasi intelijen negara adalah mengamankan kepentingan nasional. Berkaitan dengan terorisme yang terjadi di Indonesia yang merupakan salah satu ancaman yang mengganggu kepentingan nasional, maka intelijen wajib berperan serta dalam mencegah, menanggulangi dan memberantas terorisme. Intelijen tidak memiliki kewenangan dalam bidang penegakan hukum. Jika intelijen menemukan alat bukti yang menyangkut tentang pencegahan, penangkalan, dan penanggulangan ancaman keamanan nasional maka dilakukan koordinasi dengan pihak lain seperti kepolisian untuk penegakan hukum.

Deteksi Intelpampol diselenggarakan melalui jaringan Intelpampol di atas permukaan (jaringan Intelpampol struktural formal) mulai dari tingkat Polsek sampai dengan tingkat Mabes Polri dengan menetapkan Polsek sebagai Basis Deteksi Intelpampol, Polres sebagai Basis Operasional dan Polwil ke atas memberikan Back Up Operasional. ${ }^{31}$

Berdasarkan tugas dan kewenangannya maka intelijen mempunyai peran yang sangat vital dalam penganggulangan terorisme. Sesuai dengan Pasal 7 UU Nomor 17 tahun 2011 tentang Intelijen Negara maka ruang lingkup intelijen negara adalah Intelijen dalam

\footnotetext{
${ }^{30}$ UU Nomor 17 tentang Intelijen Negara Pasal 5 tahun 2011

${ }^{31}$ Priyo Widyanto, Tugas Pokok dan Fungsi Intelkam, (Balikpapan : Mediacom, 2016)
}

negeri dan luar negeri, Intelijen pertahanan dan/atau militer, Intelijen Kepolisian, Intelijen penegakan hukum, dan Intelijen kementrian/lembaga pemerintah nonkementrian.

\section{b. Tinjauan Umum Paham Radikal 1.Pengertian Paham Radikal}

Paham radikal merupakan paham keras, atau paham yang selalu memiliki ideology di luar ideology Pancasila dan UUD 194. Pengertian Radikalisme adalah suatu ideologi (ide atau gagasan) dan paham yang ingin melakukan perubahan pada sistem sosial dan politik dengan menggunakan cara-cara kekerasan/ ekstrim. Inti dari tindakan radikalisme adalah sikap dan tindakan seseorang atau kelompok tertentu yang menggunakan cara-cara kekerasan dalam mengusung perubahan yang diinginkan. Kelompok radikal umumnya menginginkan perubahan tersebut dalam tempo singkat dan secara drastis serta bertentangan dengan sistem sosial yang berlaku.

Radikalisme sering dikaitkan dengan terorisme karena kelompok radikal dapat melakukan cara apapun agar keinginannya tercapai, termasuk meneror pihak yang tidak sepaham dengan mereka. Walaupun banyak yang mengaitkan radikalisme dengan Agama tertentu, pada dasarnya radikalisme adalah masalah politik dan bukan ajaran Agama.

Menurut Muslih bahwa berasal dari bahsa Latin radix yang berarti akar, pengkal, bagian bawah, atau bisa juga berarti menyeluruh, habis-habisan dan amat keras untuk menuntut perubahan"32

Istilah radikalisme berasal dari bahasa Latin "radix" yang artinya akar, pangkal, bagian

\footnotetext{
${ }^{32}$ Muslich, Pergerakan Paham Radikalisme, (Jakarta : Kencana, 2015), h.9
} 
Media Komunikasi dan Informasi Hukum dan Masyarakat

bawah, atau bisa juga berarti menyeluruh, habis-habisan dan amat keras untuk menuntut perubahan. Menurut Kamus Besar Bahasa Indonesia (KBBI) radikalisme berarti (1) paham atau aliran yang radikal dalam politik; (2) paham atau aliran yang menginginkan perubahan atau pembaharuan sosial dan politik dengan cara kekerasan atau drastis; (3) sikap ekstrem dalam aliran politik. Radikalisme bisa dibedakan ke dalam dua level, yaitu level pemikiran dan level aksi atau tindakan. Pada level pemikiran, radikalisme masih berupa wacana, konsep dan gagasan yang masih diperbincangkan, yang intinya mendukung penggunaan cara-cara kekerasan untuk mencapai tujuan." 33

Adapun pada level aksi atau tindakan, radikalisme bisa berada pada ranah sosialpolitik dan agama. Pada ranah politik, faham ini tampak tercermin dari adanya tindakan memaksakan pendapatnya dengan cara-cara yang melawan hukum, bahkan bisa berupa tindakan mobilisasi masa untuk kepentingan politik tertentu dan berujung pada konflik sosial. Pada bidang keagamaan, fenomena radikalisme agama tercermin dari tindakantindakan anarkis atas nama agama dari sekelompok orang terhadap kelompok pemeluk agama lain (eksternal) atau kelompok seagama (internal) yang berbeda dan dianggap sesat. Termasuk dalam tindakan radikalisme agama adalah aktifitas untuk memaksakan pendapat, keinginan, dan citacita keagamaan dengan jalan kekerasan. Radikalisme agama bisa menjangkiti semua pemeluk agama, tidak terkecuali di kalangan pemeluk Islam.

\footnotetext{
${ }^{33}$ Poerwadarminta, Kamus Besar Bahasa Indonesia, (Jakarta : Balai Pustaka,
}

Menurut pengertian akademik bahwa radikal adalah Arti radikal sebenarnya netral atau positif, yaitu cara berpikir dan berperilaku yang mendasar, menggali sampai ke akar permasalahan" 34 Karena itu, menurutnya orang yang berpikir radikal biasanya melakukan lompatan jauh dalam berbagai bidang. Selanjutnya pengertian radikal dalam ilmu politik, sosial dan budaya adalah Berhubungan dengan karakteristik konstitusi yang mendasar atau melekat dari seseorang atau sesuatu hal; fundamental. Tuntutan perubahan substansial yang ekstrem di dalam suatu sistem". 35

Menurut Salito, bahwa radikal adalah Perasaan yang positif terhadap segala sesuatu yang bersifat ekstrem sampai keakar-akarnya. Sikap radikal akan mendorong individu untuk membela mengenai suatu kepercayaan, keyakinan, agama, atau ideologi yang dianutnya. ${ }^{36}$. Menurut Ali Mudhofir bahwa radikal adalah proses berfikir secara komplek sampai keakar-akarnya, sampai kepada esensi, hakikat atau substansi yang dipikirkan. ${ }^{37}$ Pengertian lain dikatakan bahwa radikalisme adalah kerelaan yang semakin tumbuh berkembang untuk mengadakan dan/atau mendukung perubahan yang sulit dijangkau dalam masyarakat yang dapat merupakan suatu bahaya terhadap (eksistensi) berlanjut dari) metode (alat) demokratis yang mungkin membahayakan fungsi aturan (efek) hukum demokratis." 38

\footnotetext{
${ }^{34}$ https://www.islampos.com/ini-pengertian-radikalmenurut-akademisi-90337/

${ }^{35}$ Zainal Arifin, Meluruskan Pengertian Radikal, (Jakarta : Rineka Cipta, 2010), h.47

${ }^{36}$ Salito Wiryawan, Paham Radikal Paham Kiri, (Jakarta : Kencana, 2013), h.47

${ }_{37}$ Ali Mudhofir, Radikalisme, (Jakarta : Ilmu Kalam, 2011), h.49

${ }^{38}$ Petur Reinhard Golose, Deradikalisasi Terorisme, (Jakarta : YPKIK, 2009), h.62
} 
Media Komunikasi dan Informasi Hukum dan Masyarakat

Berdasarkan pengertian diatas dapat digaris bawahi bahwa radikal harus ada disetiap pemeluk agama, karena dengan radikal kita belajar agama dengan menyeluruh dan utuh. Orang yang bertindak menyimpang atau yang dikonotasikan negatif akhir-akhir ini bukan termasuk berfikir radikal tetapi orang yang belajar tentang agama tidak menyeluruh dan mendalam atau berfikir positif.

Radikalisme merupakan suatu paham yang menghendaki adanya peru bahan, pergantian,dan penjebolan terhadap suatu sistem di masyarakat sampai ke akarnya. Radikalisme menginginkan adanya perubahan secara total terhadap suatu kondisi atau semua aspek kehidupan masyarakat. Tentu saja melakukan perubahan (pembaruan) merupakan hal yang wajar dilakukan bahkan harus dilakukan demi menuju masa depan yang lebih baik. Namun perubahan yang sifatnya revolusioner sering kali memakan korban lebih banyak sementara keberhasilannya tidak sebanding.

\section{Penyebab Timbulnya Paham Radikal}

Peningkatan radikalisme keagamaan banyak berakar pada kenyataan kian merebaknya berbagai penafsiran, pemahaman, aliran, bahkan sekte di dalam (intra) satu agama tertentu. Menurut Azyumardi Azra, di kalangan Islam, radikalisme keagamaan itu banyak bersumber dari: Pemahaman keagamaan yang literal, sepotong-sepotong terhadap ayat-ayat al-Qur'an. Pemahaman seperti itu hampir tidak memberikan ruang bagi akomodasi dan kompromi dengan kelompokkelompok muslim lain yang umumnya moderat, dan karena itu menjadi arus utama (mainstream) umat. Kelompok umat Islam yang berpaham seperti ini sudah muncul sejak masa al-Khulafa' al-Rasyidin keempat Ali ibn Abi
Thalib dalam bentuk kaum Khawarij yang sangat radikal dan melakukan banyak pembunuhan terhadap pemimpin muslim yang telah mereka nyatakan 'kafir'. ${ }^{39}$

Azra menambahkan bahwa bacaan yang salah terhadap sejarah Islam yang dikombinasikan dengan idealisasi berlebihan terhadap Islam pada masa tertentu. Ini terlihat dalam pandangan dan gerakan Salafi, khususnya pada spektrum sangat radikal seperti Wahabiyah yang muncul di Semenanjung Arabia pada akhir abad 18 awal sampai dengan abad 19 dan terus merebak sampai sekarang ini. Tema pokok kelompok dan sel Salafi ini adalah pemurnian Islam, yakni membersihkan Islam dari pemahaman dan praktek keagamaan yang mereka pandang sebagai bid'ah', yang tidak jarang mereka lakukan dengan cara-cara kekerasan. ${ }^{40}$

\section{Berbagai macam upaya yang} dilakukan oleh kelompok radikal dalam upaya menyebarluaskan paham radikalisme, mulai dari sistem pengkaderan langsung melalui organisasi yang dibentuk, pengajian, penyebaran informasi melalui buku dan brosur serta berita melalui media sosial.

1. Gerakan ini memiliki kecenderungan untuk menempatkan diri mereka di luar arus utama atau menolak tatanan dunia, politik dan sosial;

2. Berusaha menggulingkan tatanan politik dalam rangka membangun kembali apa yang mereka pertimbangkan tatanan alamiyah di dalam masyarakatapakah ini didasarkan pada ras, kelas, keyakinan, superioritas etnis;

3. Memiliki program ideologi dan perencanaan aksi yang ditujukan untuk meraih kekuasaan politik atau komunal;

4. Menolak atau mengacaukan konsepsi tatanan hukum masyarakat demokratis;

${ }^{39}$ Azra, Azyumardi, "Akar radikalisme keagamaan peran aparat negara, pemimpin agama dan guru untuk kerukunanumatberagama", makalah dalam workshop "Memperkuat Toleransi Melalui Institusi Sekolah"2011. 
Media Komunikasi dan Informasi Hukum dan Masyarakat

menggunakan ruang politik yang disediakan oleh sistem demokratis untuk memajukan tujuan mereka dalam mengambil kekuasaan politik;

5. Menolak deklarasi internasional hak asasi manusia dan menunjukkan ketidakempatian mereka serta tidak mengakui hak orang lain;

6. Menolak prinsip-prinsip demokrasi yang didasarkan pada kedaulatan rakyat;

7. Menolak kesetaraan secara umum terutama untuk kaum perempuan dan minoritas;

8. Menolak diversitas dan pluralisme bahkan memajukan sistem budaya yang monolitik (mono culture society);

9. Menggunakan filsafat segala cara (ends justify means) dalam mencapai tujuan;

10. Secara aktif dan mendorong dan mengutamakan penggunaan kekerasan untuk memerangi apa yang mereka pandang kejahatan dan meraih tujuan politik mereka;

11. Menunjukkan kecenderungan untuk terlibat dalam kekerasan massa terhadap musuhmusuh mereka ketika dalam kekuasaan atau keadaan impunitas;

12. Mereka biasanya menggunakan satu sudut pandang, hitam atau putih, ingin memurnikan dunia, mengumbar kebencian kepada musuh-musuh mereka;

13. Mengenyampingkan kebebasan individu untuk kepentingan kolektif;

14. Menolak kompromi dan ingin mengeliminasi musuh mereka;

15. Menunjukkan intoleransi untuk seluruh pandangan di luar pandangan mereka dan menampakkan penolakan mereka dengan cara-cara kemarahan, agresif, kebencian baik dalam perilaku maupun ucapan;

16. Menampilkan fanatisisme dan memposisikan diri sebagai pihak yang terancam serta menggunakan teori konspirasi tanpa mengaku bahwa tindakan mereka adalah irasional;

17. Menampilkan sikap diktator, otoriter dan totaliter;

18. Tidak mau dikritik dan mengintimidasi dan mengancam mereka yang berbeda, mereka yang heretik dan mereka yang kritik dengan kematian;

19. Mereka meminta agar tuntutan mereka dipatuhi.

20. Mereka memiliki ide yang tidak bisa diubah dan tertutup atas kebenaran yang mereka yakini bahkan mereka bersedia mati untuk mempertahankannya. ${ }^{43}$

\footnotetext{
${ }^{43}$ lbid
}

Karena definisi ekstremisme keagamaan itu sangat luas dan berbeda-beda, maka menanggulanginya perlulah terlibah dahulu menentukan indikator-indikatornya. Dalam hal ini merujuk 20 indikator yang bisa dijadikan sebagai parameter untuk mengukur kecenderungan ekstremisme keagamaan

Berbagai kelompok radikal yang muncul di berbagai wilayah Indonesia sejak zaman orde lama sampai hari ini dalam catatan adalah Darul Islam di Jawa Barat dan Sulawesi Selatan dan Aceh, ada Gerakan Aceh Merdeka, Al-Jama'ah Islamiyah, Gerakan Papua Merdeka, dan berbagai kelompok lain merupakan bagian dari radikalisme yang berseberangan dengan ideology Pancasila.

Upaya mengatasi radikalisme tidak cukup satu-dua elemen saja yang bekerja, namun dibutuhkan peran seluruh elemen yang mau bekerja dan bersinergi guna mewujudkan masyarakat yang aman dan damai. Pemerintah sebagai lembaga berwenang harus memberikan jaminan rasa aman dan keselamatan jiwa bagi warga negaranya. BNPT menilai UU tentang terorisme belum maksimal dalam membendung radikalisme di Indonesia. Oleh karenanya diperlukan penguatan UU terorisme agar dapat meminimalisir perkembangannya serta memnjadi payung hukum yang kuat untuk menindak tegas pelaku terorisme dan radikalisme.

Selain itu, penguatan ideologi Pancasila pada pengajaran di sekolah-sekolah maupun universitas perlu dilakukan guna meningkatkan kesadaran warga Negara akan ideologi bangsa serta kecintaan terhadap NKRI, sehingga faham-faham yang bersifat membahayakan kesatuan NKRI dapat diminimalisir. 
Media Komunikasi dan Informasi Hukum dan Masyarakat

\section{c. Tinjauan Umum Deradikalisasi}

1. Pengertian Radikalisasi

Deradikalisasi merupakan suatu upaya pemulihan, penetralisiran terhadap pelaku radikal dengan melakukan pembinaan, pemahaman dan perlindungan. Secara konsep deradikalisasi dapat diartikan sebagai "segala upaya untuk menetralisir paham-paham radikalmelalui pendekatan interdisipliner, seperti hukum,psikologi, agama dan sosial budaya bagi mereka yang dipengaruhi atau terekspose paham radikal dan/atau pro kekerasan". ${ }^{44}$ Berdasarkan defenisi di atas dapat dipahami bahwa deradikalisasi yang termasuk dalam objek deradikalisasi adalah napi, mantan napi, individu militant radikal yang pernah terlibat, keluarga, simpatisannya dan masyarakat umum. Deradikalisasi terorisme diwujudkan dengan program reorientasi motivasi, re-edukasi, resosialisasi, serta mengupayakan kesejahteraan sosial dan kesejahteraan dengan masyarakat lain bagi mereka yang pernah terlibat terorisme maupun bagi simpatisan, sehingga timbul rasa nasionalisme dan mau berpartisipasi sebagai layaknya warga Negara Indonesia.

Deradikalisasi mengacu pada tindakan preventif kontraterorisme atau stratregi untuk menetralisir paham-paham yang dianggap radikal dan membahayakan dengan cara pendekatan tanpa kekerasan. Terorisme telah menjadi permasalahan serius bagi dunia internasional karena setiap saat akan membahayakan keamanan nasional bagi negara maka dari itu program deradikalisasi dibutuhkan sebagai formula penanggulangan dan pencegahan pemahaman radikal seperti terorisme.

\footnotetext{
${ }^{44}$ Petrus Reinhard Golose, Op-Cit, h.63
}

Di dalam konteks terorisme, deradikalisasi bertujuan untuk membujuk para teroris untuk meninggalkan kekerasan yang mereka lakukan. Netralisasi menjadi tujuan dan fokus utama dari deradikalisasi pemikiran kelompok atau individu yang mempunyai ideologi radikal sehingga ia memiliki kontra radikalisme. Sebagai sebuah program deradikalisasi, menurut Counter Terrorism Implementation Task Force (CTITF) adalah sebuah kebijakan dimana memberi paket-paket bantuan sosial, hukum, politik, ekonomi dan pendidikan yang ditujukan kepada para narapidana terorisme, ini adalah salah satu tindakan yang menggunakan soft power. Pengertian deradikalisasi masih perlu untuk diperluas agar tak hanya untuk melawan terorisme melainkan harus lebih inklusif. ${ }^{45}$

Deradikalisasi merupakan semua upaya untuk mentransformasi dari keyakinan atau ideologi radikal menjadi tidak radikal dengan pendekatan multi dan interdisipliner (agama, sosial, budaya, dan selainnya) bagi orang yang terpengaruh oleh keyakinan radikal. Atas dasar itu, deradikalisasi lebih pada upaya melakukan perubahan kognitif atau memoderasi pemikiran atau keyakinan seseorang. Dengan demikian, deradikalisasi memiliki program jangka panjang. la bekerja di tingkat ideologi dengan tujuan mengubah doktrin dan interpretasi pemahaman keagamaan teroris.

\section{Tujuan Deradikalisasi}

Tujuan dari deradikalisasi ini adalah untuk mengembalikan para aktor terlibat yang

${ }^{45}$ Hikam, Muhammad A.S. Peran Masyarakat Sipil Indonesia Membendung Radikalisme - Deradikalisasi. (Jakarta: Kompas. 2016), h. viii 
Media Komunikasi dan Informasi Hukum dan Masyarakat

memiliki pemahaman radikal untuk kembali kejalan pemikiran yang lebih moderat"46.

Berdasarkan pengertian di atas maka yang menjadi tujuan deradikalisasi adalah :

i. Tujuan umum deradikalisasi adalah untuk membuat para teroris atau kelompok yang melakukan kekerasan bersedia meninggalkan atau melepaskan diri mereka dari aksi dan kegiatan terorisme.

ii. Secara khusus, tujuan deradikalisasi adalah:

Pertama, membuat para teroris mau meninggalkan aksi terorisme dan kekerasan.

Kedua, kelompok radikal mendukung pemikiran yang moderat dan toleran. Ketiga, kaum radikalis dan teroris dapat mendukung program-program nasional dalam membangun kehidupan berbangsa dan bernegara dalam bingkai Negara Kesatuan Republik Indonesia (NKRI). ${ }^{47}$

Secara spesifik, strategi di bidang deradikalisasi diarahkan kepada pencapaian dua tujuan utama: 1) Kelompok Inti dan Militan meninggalkan cara-cara kekerasan dan teror dalam memperjuangkan misinya; 2) Kelompok Inti, Militan dan Pendukung memoderasi paham-paham radikal mereka sejalan dengan semangat kelompok Islam moderat dan cocok dengan misi-misi kebangsaan yang memperkuat NKRI"48

$$
\text { Semenara tujuan Program }
$$

Deradikalisasi yang dilakukan oleh BNPT adalah sebagai berikut :

1. Membina narapidana terorisme agar meninggalkan pandangan, pemikiran,

${ }^{46}$ Pusbangdatin. "Detailpost - Program Deradikalisasi sebagai upaya Pencegahan Terjadinya Tindakan Terorisme di Indonesia". Badan Penelitian dan Pengembangan Hukum dan HAM I Kementerian Hukum dan HAM Republik Indonesia (dalam bahasa Inggris). Diakses tanggal 201710-02.

${ }^{47}$ Media, Kompas Cyber. "Jokowi Bentuk Unit Kerja Pembinaan Pancasila - Kompas.com". KOMPAS.com (dalam bahasa Inggris). Diakses tanggal 2017-10-02

${ }^{48}$ Leila Ezzarque, Proses Deradikalisasi, (Jakarta : Kencana, 2015), h.87 sikap, dan tindakan radikal terorisme melalui pendekatan agama, sosial, budaya, dan ekonomi;

2. Memberikan pencerahan pemikiran kepada narapidana terorisme dengan pengetahuan agama yang damai dan toleran serta wawasan kebangsaan dalam kerangka Negara Kesatuan Republik Indonesia;

3. Membina kemandirian kepada narapidana terorisme berupa pembekalan keterampilan, keahlian, dan pembinaan kepribadian;

4. Mempersiapkan narapidana terorisme sebelum kembali dan hidup berdampingan dengan masyarakat;

5. Membina dan memberdayakan keluarga narapidana terorisme dan masyarakat agar dapat menerima kembali mantan narapidana teroris untuk dapat bersosialisasi di tengah masyarakat;

6. Memberdayakan mantan narapidana terorisme, keluarga, dan masyarakat dengan pendekatan agama, sosial, pendidikan, budaya, dan ekonomi;

7. Memberdayakan masyarakat dalam rangka meninggalkan paham dan sikap radikal terorisme yang berkembang di tengah masyarakat; ${ }^{49}$

Pelaksanaan deradikalisasi di Indonesia dirumuskan sebagai suatu program yang utuh, integratif, dan berkesinambungan dengan dua klasiifikasi, yaitu Deradikalisasi di Luar Lapas dan Deradikalisasi di Dalam Lapas. Deradikalisasi di luar lapas mencakup tahap identifikasi, pembinaan kontra radikalisasi, dan monitoring dan evaluasi. Sementara Deradikalisasi di Dalam Lapas meliputi tahap identifikasi, rehabilitasi, reedukasi, resosialisasi, dan monitoring dan evaluasi. Program Deradikalisasi dilaksanakan secara bertahap agar tujuan dan sasaran dapat dicapai secara efektif.

Deradikalisasi di dalam Lapas memiliki sasaran para Narapidana tindak pidana terorisme yang tersebar di berbagai lapas di Indonesia. Sementara, deradikalisasi di luar Lapas memiliki sasaran :

${ }^{49}$ BNPT, Program Deradikalaisasi, (Jakarta : BNPT, 2017), h.4 
Media Komunikasi dan Informasi Hukum dan Masyarakat

1. Individu, yaitu seseorang yang diindikasikan berpikiran radikal-teroris;

2. Kelompok, yaitu sekumpulan orang yang bergabung dalam oraganisasi yang diindikasikan berpikiran radikal-teroris;

3. Keluarga, yaitu keluarga inti dari individu atau kelompok yang terindikasi radikal. Keluarga ini juga dapat diperluas pada keluarga terdekatnya jika dipandang bahwa keluarga terdekat tersebut juga terindikasi berpaham radikal atau memberikan dukungan terhadap paham/aksi radikal terorisme; $; 0$

Berdasarkan uraian di atas dapat dipahami bahwa deradikalisasi dilakukan dalam lapas bagi yang masih menjalani hukuman, dan di luar lapas bagi yang sudah bebas masa hukuman maupun kepada masyarakat umum.

A.S Hikam dalam bukunya yang berjudul "Peran Masyarakat Sipil Indonesia Membendung Radikalisme - Deradikalisasi" menyatakan bahwa ada tiga subjek Deradikalisasi , yaitu :

1. Suprastruktur yang merujuk pada peran pemerintah pusat maupun daerah, peran suprastruktur ini ditopang oleh berbagai undang-undang kontraterorisme seperti UU No. 15/2003 tentang Pemberantasan Tindak Terorisme, UU No. 15/2003 tentang $\mathrm{TNI}$ yang mengamanatkan penghadapan ancaman atas negara dari pelaku nonnegara, UU No. 3/2002 tentang Pertahanan Nasional, Peraturan Presiden Nomor 12/2002 tentang Pertahanan Nasional Penanggulangan Terorisme, sampai UU No. 17/2013 tentang Organisasi Kemasyarakatan yang melarang ideologi kontra Pancasila.

2. Infrastruktur yang merujuk pada lembaga pelaksana deradikalisasi, baik dari pemerintah maupun masyarakat. ${ }^{51}$

$$
\text { Subjek dari deradikalisasi }
$$

sebagaimana uraian di atas adalah merupakan supsttukrue dan infrastruktur. Selanjutnya yang menjadi mekna dalam deradikalisasi sebagaimana yang dikatakan oleh AS Hikam

\footnotetext{
50 Ibid.

5150 AS.Hikam, Op-Cit, h.85
}

bahwa terdapat dua makna dalam deradikalisasi yaitu pemutusan dan deideologisasi yaitu :

1. Pemutusan (Disengagment) Pemutusan bisa berarti mendorong kelompok radikal untuk meorientasi diri melalui perubahan sosial kognitif sehingga mereka meninggalkan pemahaman radikal yang mereka anut sebelumnya, menuju norma yang baru dalam artian menuju kembali kepemikiran yang tidak radikal.

2. Deideologisasi (Deidelogization) artinya penghapusan ideologi atas agama serta agama tidak dipandang sebagai ideologi politik melainkan dapat dipahami sebagai nilai-nilai luhur yang menyemai pesan perdamaian. Kemunculan Negara Islam Irak dan Suriah telah menimbulkan presepsi bahwa agama dijadikan ideologi politik sehingga mudah untuk merekrut anggota baru yang pemikiran agamanya sesuai dengan pemikiran mereka. ${ }^{52}$

Di Indonesia, pemerintah telah melakukan berbagai strategi untuk menangkal pemahaman radikal seperti pembentukan Unit Kerja Presiden Pembinaan Ideologi Pancasila, pembentukan unit tersebut diharapkan mampu mempersempit gerak ideologi-ideologi radikal. Pemerintah juga melakukan pendekatan terhadap narapidana terorisme dilapas melalui rehabilitasi baik itu dengan pendekatan karakter kebangsaan dan menanamkan nilainilai perdamaian, serta peran aktif ormas keagamaan dalam mempromosikan nilai-nilai pluralisme seperti yang dilakukan oleh Nahdlatul Ulama dan Muhammadiyah. ${ }^{53}$ Sasaran utama dari sosialisasi deradikalisasi adalah tahanan ataupun mantan teroris serta sangat diperlukan dan dibutuhkan dukungan dari berbagai pemangku kekuasaan, lebih lagi sosialisasi deradikalisasi juga perlu diperuntukan kepada komunitas-komunitas

$$
52 \text { Ibid. }
$$

${ }^{53}$ Indonesia, CNN. "Jokowi Pamer Kesuksesan Deradikalisasi Indonesia di KTT G20". CNN Indonesia (dalam bahasa Inggris). Diakses tanggal 2017-10-02. 
Media Komunikasi dan Informasi Hukum dan Masyarakat

masyarakat yang potensial di masuki paham radikal.

Ada beberapa langkah yang dilakukan dalam menangani deradikalisasi di Indonesia, antara lain :

1. Pertama, netralisasi atau mengubah paham radikal kelompok-kelompok atau individu perekrut pelaku teror. "Menetralisirnya dengan cara persuasif, mengubahnya menjadi moderat dengan program counter ideology sehingga orang yang pahamnya radikal menjadi moderat," kata Tito.

2. Kedua, cara koersif yang menekankan pada langkah-langkah keamanan seperti melibatkan militer, intelijen dan kepolisian yang dipayuki undang-undang.

3. Ketiga, netralisasi segmen masyarakat yang menjadi target indoktrinasi radikalisme, melalui kajian wilayah-wilayah mana saja yang masyarakatnya rentan menjadi target paham radikal.

4. Keempat, program counter media di dunia maya, untuk melawan media-media digital yang dimanfaatkan kelompok radikal untuk menyebarkan pahamnya.

5. Kelima, memanfaatkan penelitian para ahli, ilmu sosial dan ulama terkait alasan suatu wilayah kerap dijadikan tempat penyebaran paham radikal atau menjadi sasaran aksi teror. $^{54}$

Sesuai dengan paparan tersebut di atas, jelaslah bahwa deradikalisasi merupakan perubahan pola dalam penanganan kelompok radikal atau terorisme saat ini. Deradikalisasi yang menjadi formula terbaru untuk mengatasi ancaman terorisme memiliki kaitan dengan deidiologisasi. Dimana tujuan deradikalisasi tersebut untuk mengembalikan dan menormalisasikan para pelaku radikal kepada paham sebelumnya.

\section{Program Deeradikalisasi}

Program deradikalisasi berupaya melepaskan ideology-ideologi dari dalam diri pelaku radikal/teroris, atau menghentikan

\footnotetext{
${ }^{54}$ Tito Karnavian, Lima Langkah Deradikalisasi, (Jakarta : Netralnewscom, 2017)
}

proses penyebaran ideology,program ini disebut sebagai deideologisasi. Istilah tersebut berasal dari kata dasar ideology dengan awalan de-serta ditambahi dengan akhiran isasi. Menurut Kamus Umum Bahasa Indonesia ideology adalah :

1. Kumpulan konsep bersistem yang dijadikan atas pendapat (kejadian) yang memberikan arahan dan tujuan untuk kelangsungan hidup.

2. Cara berpikir seseorang atau suatu golongan

3. Paham, teori, dan tujuan yang berpadu merupakan suatu program sosial politik." 55

Pengertian ideologi berdasarkan konsep sebagaimana di atas dapat dipahami bahwa sebagai kumpulan konsep dan teori yang dipadukan secara tersistem dan terprogram. Sementara dalam konsep politik dapat diartikan sebagai :

1) Sistem kepercayaan yang menerangkan dan pembenaran suatu tatanan politik yang ada atau yang dicita-citakan dan memberikan strategi berupa prosedur, rancangan, instruksi serta program untuk pencapaiannya.

2) Himpunan nilai, ide, norma, kepercayaan dan keyakinan yang dimiliki seseorang atau sekelompok ornag yang menjadi dasar dalam menentukan sikap terhadap kejadian dan problem politik yang dihadapinya dan yang menentukan tingkah laku politik. ${ }^{56}$

Deideologisasi sebagaimana pengertian tersebut memberikan pengertian sebagai proses pendalaman (penyebaran) ideology. Implikasi deideologi yang dikemukakan sebelumnya berbeda dengan deideologisasi yang terjadi pada zaman orde baru. Ketika itu, Pancasila dijadikan sebuah ideology tunggal dan tidak boleh menganut ideology apapun selain Pancasila. Zaman orde

\footnotetext{
${ }^{55}$ WJS. Poerwadarminta, Kamus Umum, h.366

${ }^{56} \mathrm{lbid}$
} 
Media Komunikasi dan Informasi Hukum dan Masyarakat

baru deideologisasi berimplikasi pada dilarangnya pembentukan partai yang berlandaskan agama, terutama terhadap Islam dan komunis. Deideologisasi dalam warna baru hanya menghentikan ideology yang dijadikan dasar tindakan terorisme, ataupun ideology yang mengancam kehidupan berbangsa dan bernegara dalam segala pluralitas serta kehidupan berdemokrasi.

$$
\text { Dapat disimpulkan bahwa }
$$

deradikalisasi atau deideologisasi adalah suatu upaya untuk menghentikan proses pemahaman dan penyebaran ideology Islam radikal yang dimiliki oleh kelompok teroris. Sehingga deideologisasi menjadi kunci utama dalam penyadaran atau proses reorientasi pemikiran teroris agar dapat kembali kepada pemahaman Islam yang hakiki.

Deradikalisasi yang diwujudkan melalui suatu program memiliki kesamaan karakteristik di beberapa Negara. Persamaan program tersebutr dketahui oleh CTTITF ada sebelas jenis, antara lain :

1. Pelibatan dan kerjasama dengan masyarakat umum

2. Pelaksanaan program khusus dalam penjara

3. Program pendidikan

4. Pengembangan dialog lintas budaya

5. Pengupayaan keadilan sosial dan ekonomi

6. Kerjasama global dalam penanggulangan terorisme

7. Pengawasan terhadap cyber terorisme

8. Perbaikan perangkat perundang-undangan

9. Program rehabilitasi

10. Pengembangan dan penyebaran informasi regional

11. Pelatihan serta kualifikasi para agen yang terlihat dalam melaksanakan kebijakan kontra radikalisasi" 57

Selain program deradikalisasi di atas, beberapa program yang cukup efektif dilakukan dalam rangka deradikalisasi, antara lain :

\footnotetext{
${ }^{57}$ Petrus, Deradikalisasi, h.66
}

1. Persuasif

Program persuasif dapat mengatasi keterbatasan hukum pidana, program tersebut juga tidak akan berbenturan dengan Hak Azasi Manusia yang telah dilindungi oleh hukum nasional atau internasional. Program yang sifatnya sosial dapat diberikan kepada orang-orang yang belum melakukan tindakan pidana atau kepada anggota masyarakat yang menjadi simpatisan dan belum terlibat aksi terorisma atau radikal. Dalam kondisi seperti ini mereka harus segera dilibatkan dalam program deradikalisasi, hal ini menjadi penting untuk mengeliminasi bahaya laten radikalisme.

2. Program reorientalisasi motivasi dan reedukasi dapat dilakukan lewat dialog, forum diskusi, debat terbuka atau pembuatan kelas khusus untuk penanganan secara intensif. Pembinaan kejiwaan yang dilakukan oleh para psikolog,psikiater dan konselor sangat berguna untukmengatasi masalah mental yang dihadapi oleh para tahanan dan napi, sedangkan re-edukasi diberikan oleh pemuka agama, atau mantan pelaku radikal yang telah sadar.

3. Program perbaikan manajemen

Program perbaijkan manajemen lembaga pemasyarakatan memiliki fungsi agar penjara tidak lagi dapat dijadikan sebagai tempat sekolah kelompok radikal bagi napi non radikal atau napi radikalisme menjadi semakin radikal. Perbaikan manajemen kemudian ditingkatkan seperti halnya penerapan focus penanganan terpadu terhadap napi paham radikal.

4. Program kampanye

Program kampanye terhadap radikalisme/terorisme tetap dijalankan agar seluruh lapisan masyarakat mengetahui segala bentuk bahaya dan ancaman terror dari para teroris. Tujuan program ini untuk melindungi masyarakat agar tidak terkena pengaruh ideology teroris. Program tersebut dapat dilakukan melalui internet, media, pemutaran film, pembuatan buku dan lain sebagainya. ${ }^{58}$

Dari sekian banyak program yang dijalankan, program rehabilitasi dan re-edukasi lebih dikenal dengan istilah deradikalisasi sampai saat ini, masih menjadi kajian segar bagi berbagai Negara yang memiliki tujuan

\footnotetext{
58 lbid, h.67
} 
Media Komunikasi dan Informasi Hukum dan Masyarakat

untuk menerapkan konsep deradikalisasi di dalam negaranya. Program deradikalisasi dalam tataran nyata memiliki karakter penanganan kejahatan terorisme atau kelompok radikal yang berbeda dari cara tradisional. Karakteristik yang jelas Nampak adalah metode penyelesaian masalah dilakukan melalui kontra terorisme yang bersifatg pendekatan dan melalui pendekatan budaya.

Pendekatan budaya memiliki maksud untuk menyelami dan menjiwai suatu masalah dalam menyelesaikan permasalahan tersebut lewat etika, moralitas, estetika dan nilai kemanusiaan yang terdapat pada budaya tersebut". ${ }^{59}$

Kemudian program deradikalisasi yang bersifat sosial juga sering dilakukan dengan cara :

1. Pemberian bantuan untuk menfasilitasi acara pernikahan

2. Peningkatan pelayanan sosial

3. Pembuatan perencanaan untuk membantu keluarga napi dalam mencari nafkah untuk hidup

4. Pemberian bantuan biaya pendidikan serta kesehatan kepada keluarga dan anak yang memiliki orangtua pelaku radikal yang sedang di penjara

5. Pemberian bantuan pinjaman dana kepada para napi yang telah bebas agar mereka dapat membuka usaha

6. Pembentukan badan amal dan bekerjasama dengan pemerintahuntuk mendirikan sekolah

Program pelatihan bagi para napi dalam rangka membantu mencarikan pekerjaan"60

Fasilitas-fasilitas yang tersedia di pusat rehabilitasi dan berbagai program yang dilakukan oleh pemerintah terutama melalui pendekatan budaya, agama menjadi program yang dianggap efektif dalam melakukan

${ }^{59}$ Suparlan, Menuju Masyarakat Indonesia yang Multikultural, 2009, Diakses dari Situs http//www.duniaesai.com/antra.htm.2008

60 Petrus, Deradikalisasi, h.73 deradikalisasi di Indonesia. Melalui berbagai program tersebut tentunya kondisional bagi setiap daerah atau wilayah di seluruh Indonesia. Namun pada prinsipnya deradikalisasi adalah upaya untuk menormalkan dan mengembalikan paham radikal/teroris yang sedang dalam penjara maupun bagi mereka yang sudah keluar dari penjara serta bagi masyarakat umum yang sudah menjadi simpatisan terhadap pahama radikal tersebut.

Adapun upaya yang dilakukan oleh Kepolisian dalam menangani radikalisme mengacu kepada peraturan dan Undangundang yang berlaku.

Khusus menangani kelompok radikalisme maka Kepolisian mengacu kepada dasar hukum dan peraturan antara lain Undang-Undang Republik Indonesia Nomor 5 TAHUN 2018 Tentang Perubahan Atas Undang-Undang Nomor 15 tahun 2003 Tentang Penetapan Peraturan Pemerintah Pengganti Undang-Undang Nomor 1 TAHUN 2002 tentang pemberantasan tindak pidana terorisme menjadi undang-undang terdiri dari :.

1. Pasal I Dalam Undang-Undang ini yang dimaksud dengan:

a) Tindak Pidana Terorisme adalah segala perbuatan yang memenuhi unsur-unsur tindak pidana sesuai dengan ketentuan daiam UndangUndang ini.

b) Terorisme adalah perbuatan yang menggunakan kekerasan atau ancaman kekerasan yang menimbulkan suasana teror atau rasa takut secara meluas, yang dapat menimbulkan korban yang bersifat massal, dan/atau menimbulkan kerusakan atau kehancuran terhadap objek vital yang strategis, lingkungan hidup, fasilitas publik, atau fasilitas internasional dengan motif ideologi, politik, atau gangguan keamanan.

2 Pasal I2A (1) Setiap Orang yang dengan maksud melakukan Tindak Pidana Terorisme di wilayah Negara Kesatuan 
Media Komunikasi dan Informasi Hukum dan Masyarakat

Republik Indonesia atau di negara lain, merencanakan, menggerakkan, atau mengorganisasikan Tindak Pidana Terorisme dengan orang yang berada di dalam negeri dan/ atau di luar negeri atau negara asing dipidana dengan pidana penjara paling singkat 3 (tiga) tahun dan paling Lama 12 (dua belas) tahun. Setiap Orang yang dengan sengaja menjadi anggota atau merekrut orang untuk menjadi anggota Korporasi yang ditetapkan dan/atau diputuskan pengadilan sebagai organisasi Terorisme dipidana dengan pidana penjara paling singkat 2 (dua) tahun dan paling lama 7 (tujuh) tahun. Pendiri, pemimpin, pengurus, atau orang yang rnengendalikan Korporasi sebagairnana dimaksud pada ayat (2) dipidana dengan pidana penjara paling singkat 3 (tiga) tahun dan paling lama 12 (dua belas) tahun.

3. Pasal 128 (1) Setiap Orang yang (2) (3) (4) dengan sengaja menyelenggarakan, memberikan, atau mengikuti pelatihan militer, pelatihan paramiliter, atau pelatihan lain, baik di dalam negeri maupun di luar negeri, dengan maksud merencanakan, mempersiapkan, atau melakukan Tindak Pidana Terorisme, dan/atau ikut berperang di luar negeri untuk Tindak Pidana Terorisme dipidana dengan pidana penjara paling singkat 4 (empat) tahun dan paling lama 15 (lima belas) tahun. Setiap Orang yang dengan sengaja merekrut, menampung, atau mengirim orang untuk mengikuti pelatihan sebagaimana dimaksud pada ayat (1) dipidana dengan pidana penjara paling singkat 4 (empat) tahun dan paling lama 15 (lima belas) tahun. Setiap Orang yang dengan sengaja membuat, mengumpulkan, dan/atau menyebarluaskan tulisan atau dokumen, baik elektronik maupun nonelektronik untuk digunakan dalam pelatihan sebagaimana dimaksud pada ayat (1) dipidana dengan pidana penjara paling singkat 3 (tiga) tahun dan paling lama 12 (dua belas) tahun. Setiap warga negara Indonesia yang dijatuhi pidana Terorisme sebagaimana dimaksud pada ayat (1) sampai dengan ayat (3) dapat dikenakan pidana tambahan berupa pencabutan hak untuk memiliki paspor dan pas iintas batas dalam jangka waktu paling lama 5 (lima) tahun

Pasai 13A Setiap Orang yang memiliki hubungan dengan organisasi Terorisme dan dengan sengaja menyebarkan ucapan, sikap atau perilaku, tulisan, atau tampilan dengan tujuan untuk menghasut orang atau kelompok orang untuk melakukan Kekerasan atau Ancaman Kekerasan yang dapat mengakibatkan Tindak Pidana Terorisme dipidana dengan pidana penjara paling lama 5 (lima) tahun. ${ }^{61}$

Undang-undangan tersebut di atas menjadi dasar bagi Kepolisian Republik Indonesia untuk memberantas pergerakan paham radikalisme di Indonesia. Adapun upaya yang dilakukan oleh Kepolisian Republik Indonesia secara hukum penal dalam menangani paham radikalisme adalah melakukan penegakan hukum sesuai dengan peraturan dan undang-undang terorisme sebagai berikut :

1. Penegakan KUHP

Pasal 139 ayat 1 : dihapuskan karena tidak sesuai dengan susunan kenegaraan Republik Indonesia. Dicabut oleh undang undang nomor 1 tahun 1946.

Pasal 139 ayat 2, berbunyi :

Pada waktu menjatuhkan hukuman karena salah satu kejahatan yang diterangkan dalam pasal 131, maka dapat dijatuhkan hukuman mencabut hak yang tersebut dalam pasal 35 nomor 1e sampai $4 \mathrm{e}$.

Pasal 139 ayat 3 , berbunyi :

Pada waktu menjatuhkan hukuman karena salah satu kejahatan yang diterangkan dalam pasal 136, maka dapat dijatuhkan hukuman mencabut hak yang tersebut dalam pasal 35 nomor 1e sampai $3 e$.

Pasal 111 KUHP ayat 1.

Pasal 111 (1) Barang siapa mengadakan hubungan dengan negara asing dengan maksud menggerakkannya untuk melakukan perbuatan permusuhan atau perang terhadap negara, memperkuat niat mereka, menjanjikan bantuan atau membantu mempersiapkan mereka untuk melakukan perbuatann permufakatan atua perang terhadap negara, diancam dengan pidana penjara paling lama lima belas tahun. (2) Jika perbuatan permusuhan dilakukan atau terjadi perang, diancam dengan pidana mati atua pidana penjara seumur hidup atau pidana penjara sementara paling lama dua puluh tahun.

\footnotetext{
6160 UU RI No.5 Tahun 2018 Tentang Pemberantasan Tindak Pidana Terorisme
} 
Media Komunikasi dan Informasi Hukum dan Masyarakat

2. Tegakkan UU No. 15/2003 tentang Terorisme,

Undang-Undang Nomor 15 Tahun 2003 Tentang Penetapan Peraturan Pemerintah Pengganti Undang-Undang Nomor 1 Tahun 2002 Tentang Pemberantasan Tindak Pidana Terorisme, Menjadi Undang-Undang jo. Peraturan Pemerintah Pengganti Undang-Undang Republik Indonesia Nomor 1 Tahun 2002 Tentang Pemberantasan Tindak Pidana Terorisme

Pasal 6

Setiap orang yang dengan sengaja menggunakan kekerasan atau ancaman kekerasan menimbulkan suasana teror atau rasa takut terhadap orang secara meluas atau menimbulkan korban yang bersifat massal, dengan cara merampas kemerdekaan atau hilangnya nyawa dan harta benda orang lain, atau mengakibatkan kerusakan atau kehancuran terhadap obyek-obyek vital yang strategis atau lingkungan hidup atau fasilitas publik atau fasilitas internasional, dipidana dengan pidana mati atau penjara seumur hidup atau pidana penjara paling singkat 4 (empat) tahun dan paling lama 20 (dua puluh) tahun.

Pasal 9

Setiap orang yang secara melawan hukum memasukkan ke Indonesia, membuat, menerima, mencoba memperoleh, menyerahkan atau mencoba menyerahkan, menguasai, membawa, mempunyai persediaan padanya atau mempunyai dalam miliknya, menyimpan, mengangkut, menyembunyikan, mempergunakan, atau mengeluarkan ke dan/atau dari Indonesia sesuatu senjata api, amunisi, atau sesuatu bahan peledak dan bahan-bahan lainnya yang berbahaya dengan maksud untuk melakukan tindak pidana terorisme, dipidana dengan pidana mati atau penjara seumur hidup atau pidana penjara paling singkat 3 (tiga) tahun dan paling lama 20 (dua puluh) tahun

$$
\text { Pasal } 14
$$

Setiap orang yang merencanakan dan/atau menggerakkan orang lain untuk melakukan tindak pidana terorisme sebagaimana dimaksud dalam Pasal 6, Pasal 7, Pasal 8, Pasal 9, Pasal 10, Pasal 11, dan Pasal 12 dipidana dengan pidana mati atau pidana penjara seumur hidup.

Pasal 15

Setiap orang yang melakukan permufakatan jahat, percobaan, atau pembantuan untuk melakukan tindak pidana terorisme sebagaimana dimaksud dalam Pasal 6, Pasal 7, Pasal 8, Pasal 9,
Pasal 10, Pasal 11, dan Pasal 12 dipidana dengan pidana yang sama sebagai pelaku tindak pidananya.

Pasal 16

Setiap orang di luar wilayah negara Republik Indonesia yang memberikan bantuan, kemudahan, sarana, atau keterangan untuk terjadinya tindak pidana terorisme, dipidana dengan pidana yang sama sebagai pelaku tindak pidana sebagaimana dimaksud dalam Pasal 6, Pasal 7, Pasal 8, Pasal 9, Pasal 10, Pasal 11, dan Pasal 12.

Pasal 19

Ketentuan mengenai penjatuhan pidana minimum khusus sebagaimana dimaksud dalam Pasal 6, Pasal 8, Pasal 9, Pasal 10, Pasal 11, Pasal 12, Pasal 13, Pasal 15, Pasal 16 dan ketentuan mengenai penjatuhan pidana mati atau pidana penjara seumur hidup sebagaimana dimaksud dalam Pasal 14, tidak berlaku untuk pelaku tindak pidana terorisme yang berusia di bawah 18 (delapan belas) tahun.

3. Tegakkan UU No. 11/2008 tentang informasi dan transaksi elektronik

Pasal 28 (1) Setiap Orang dengan sengaja dan tanpa hak menyebarkan berita bohong dan menyesatkan yang mengakibatkan kerugian konsumen dalam Transaksi Elektronik. (2) Setiap Orang dengan sengaja dan tanpa hak menyebarkan informasi yang ditujukan untuk menimbulkan rasa kebencian atau permusuhan individu dan/atau kelompok masyarakat tertentu berdasarkan atas suku, agama, ras, dan antargolongan (SARA). Penjelasan: Pasal 28 Cukup jelas. 3 Pasal 29 Setiap Orang dengan sengaja dan tanpa hak mengirimkan Informasi Elektronik dan/atau Dokumen Elektronik yang berisi ancaman kekerasan atau menakut-nakuti yang ditujukan secara pribadi. Pelanggar pasal ini akan didenda paling banyak Rp2.000.000.000,00 (dua miliar rupiah) atau penjara 6 bulan. ${ }^{62}$

Ketentuan di atas merupakan

ketentuan hukum penal atau tindakan hukum secara normative, sedangkan pelanggar tindakan non penal terhadap paham radikalisme akan dilakukan dengan berbagai tindakan sebagai berikut :

\section{Kerangka Konsep}

${ }^{6}$ Ibid 
Media Komunikasi dan Informasi Hukum dan Masyarakat

Berbagai kebijakan hukum kriminal sebagai wujud komitmen negara secara tegas telah mengatur baik dari pendekatan penal dan non penalDitilik dalam acuan kebijakan tersebut sebagai payung hukum, ada dua model pendekatan kebijakan yang tergambar yakni : Pendekatan Penal yakni : penerapan hukum pidana guna menjerat pelaku dalam memaksimalkan hukum untuk memberikan efek jera, melalui proses pemeriksaan di tingkat Polisi, Jaksa dan Hakim di Pengadilan ${ }^{63}$.

Sebelum terjadinya kasus melalui upaya pencegahan dengan peningkatan penyadaran, pemahaman dan kepedulian masyarakat luas guna berperan serta dalam melakukan antisipasi sedini mungkin dan perlindungan bagi korban perdagangan orang, setelah terjadinya kasus melalui upaya perlindungan, reintegrasi, rehabilitasi sosial dan kesehatan serta pemulangan korban.

Teori Kebijakan Kriminal sebagaimana di kemukakan oleh G. Peter Hoefnagles bahwa Kebijakan Kriminal adalah "satu usaha yang rasional dari pemerintah dan masyarakat dalam melakukan penanggulangan dilakukan melalui :

a. Criminal policy is the science of responses "kebijakan kriminal merupakan ilmu tanggapan"

b. Criminal policy is the science of crime prevention "kebijakan kriminal merupakan ilmu pencegahan"

c. Criminal Policy is a policy of designating human behavior as crime "kebijakan criminal merupakan kebijakan yang dapat merubah prilaku manusia untuk berbuat lebih baik"

d. Criminal Policy is a rational total of the responses to crime "kebijakan criminal merupakan tanggapan dari seluruh

${ }^{63}$ Satjipto Rahardjo, Pidato mengakhiri masa jabatan sebagai Guru Besar Tetap pada Fakultas Hukum Universitas Diponegoro,15 Desember 2000, h,11 pemangku kebijakan terhadap dampak satu kejahatan"64

Sinergitas teori pencegahan diatas dikaitkan dengan rumusan latar belakang pola alur kinerja dari UU No. 15/2003 tentang Pemberantasan Tindak Terorisme, UU No. 15/2003 tentang TNI yang mengamanatkan penghadapan ancaman atas negara dari pelaku non-negara, UU No. 3/2002 tentang Pertahanan Nasional, Peraturan Presiden Nomor 12/2002 tentang Pertahanan Nasional Penanggulangan Terorisme, sampai UU No. 17/2013 tentang Organisasi Kemasyarakatan yang melarang ideologi kontra Pancasila, erat kaitanya dengan konsep teori yang digambarkan G. Peter Hofnagels bagaimana semua disiplin ilmu menjadi bagian dari kebijakan kriminal sebagai upaya pencegahan kejahatannya yang ditempuh lewat:

a. Penerapan hukum pidana (criminal law application) secara penal;

b. Pencegahan tanpa pidana (prevention without punishment) secara non penal

Mempengaruhi pandangan masyarakat mengenai kejahatan dan pemidanaan lewat media massa (influencing views of society on crime and punistment/mass media) yang juga merupakan pendekatan non penal. Kebijakan pencegahan sebelum terjadinya kejahatan dari konsep diatas menekankan upaya pendekatan penanganan terhadap penyebab kejahatan itu terjadi sebagai bagian masalah sosial secara langsung dan tidak langsung dapat menimbulkan tumbuh suburnya kejahatan sehingga dimungkinkan pencegahan non penal ini mempunyai kedudukan yang penting jika

${ }^{64}$ Barda Nawawi Arief, Kebijakan legislatif dalam Penanggulangan Kejahatan dengan Pidana Penjara,

(Badan Penerbit Universitas Diponegoro.Semarang. 2000), .h 32 
Media Komunikasi dan Informasi Hukum dan Masyarakat

difungsikan dan diefektifkan dalam mengurangi korban perdagangan orang lebih banyak lagi.

Kalau ilmu pengetahuan didefinisikan sebagai institusi pencarian kebenaran, maka pada waktu yang sama harus dikatakan bahwa pencarian kebenaran itu adalah proses yang dramatis. IImu pengetahuan memang berburu kebenaran, tetapi sekaligus juga disadari, bahwa kebenaran itu sendiri, kebenaran absolut, tidak pernah akan ditemukan. Memang suatu yang tragis, tetapi benar, karena hanya Allah tempat kebenaran yang sempurna.

Bertolak dari hal tersebut di atas, dalam rangka menanggulangi paham radikal yang semakin marak terjadi di Indonesia akhirakhir ini, diperlukan suatu ilmu yang dapat memberi solusi antisipatif dalam rangka mencegah terjadinya kerusuhan maupun ketidak stabilan sosial, sehingga tujuan bangsa sebagaimana termaktub dalam pembukaan Undang-undang Dasar 1945 dan pembangunan nasional tidak terhambat.

Soedarto menyatakan, bahwa apabila hukum pidana hendak dilibatkan dalam usahausaha mengatasi segi negatif perkembangan masyarakat, maka hendaknya dilihat dalam hubungan keseluruhan politik kriminal atau social defense planning. Selanjutnya social defense planning ini harus merupakan bagian intergral dari rencana pembangunan nasional.

Sehubungan dengan hal tersebut di atas, Oemar Senoadji mengemukakan tiga teori mengenai delik agama, yaitu;

1. Friedensschutz Theorie, yaitu yang memandang ketertiban/ ketentraman umum sebagai kepentingan hukum yang dilindungi

2. Gefuhlsschutz Theorie, yaitu teori yang memandang rasa keagamaan sebagai kepentingan hukum yang harus dilindungi

3. Religionsschutz Theorie, yaitu teori yang memandang agama itu ansich sebagai kepentingan hukum yang harus dilindungi/ diamankan oleh Negara. ${ }^{65}$

Teori di atas, secara tidak langsung memberikan sinyal bahwa harus ada paradigma baru, cara pandang baru dan kebijakan secara menyeluruh, terutama kebijakan kriminal yang harus segera ditempuh oleh Negara dalam menyelesaikan berbagai masalah, terutama aliran sesat ini

G P. Hoefnagels menguraikan beberapa upaya penanggulangan kejahatan, yaitu; penerapan hukum pidana (criminal law application); pencegahan tanpa pidana (prevention without punishment); mempengaruhi pandangan masyarakat tentang kejahatan ; dan pemidanaan melalui media masa (influencing views of society on crime and punishment/mass media)." 66

Berdasarkan pendapat $G \quad P$. Hoefnagels diatas dapat disimpulkan bahwa Penanggulangan kejahatan (termasuk aliran sesat) secara umum dapat ditempuh melalui dua pendekatan yaitu penal dan non penal. Keduanya dalam fungsinya harus berjalan beriringan secara sinergis, saling melengkapi. Jika pendekatan pertama yang ditempuh, maka ini berarti bahwa penanggulangan suatu kejahatan dilakukan dengan menggunakan kebijakan hukum pidana (penal policy/criminal law policy/strafrechtspolitiek), yaitu, "usaha mewujudkan peraturan perundang-undangan pidana yang sesuai dengan keadaan dan situasi pada suatu waktu dan untuk masa yang akan datang" . Artinya, hukum pidana difungsikan sebagai sarana pengendali sosial, yaitu dengan sanksinya yang berupa pidana

\footnotetext{
${ }^{65}$ Oemar Senoadji, Hukum (Acara) Pidana Dalam Prospeksi. (Erlangga, Jakarta 1996), h. 75 66 Ibid.
} 
Media Komunikasi dan Informasi Hukum dan Masyarakat

untuk dijadikan sarana menanggulangi kejahatan. ${ }^{67}$

Dengan demikian diharapkan normanorma sosial dapat ditegakkan dengan sanksi yang dimiliki hukum pidana terhadap seseorang yang berperilaku tidak sesuai dengan norma-norma tersebut. Apabila dilihat dari sudut kebijakan kriminal, upaya penanggulangan paham radikal dengan menggunakan sarana penal bukan kebijakan yang strategis, karena kebijakan mempunyai keterbatasan dan mengandung beberapa kelemahan (sisi-sisi negatif)

Jadi, jika dilihat dari sudut kebijakan, maka penggunaan atau intervensi penal seyogyanya dilakukan dengan lebih hati-hati, cermat, hemat, selektif dan limitatif. Hal ini penting dilakukan dalam Dalam hal ini marc Ancel mendefinisikan penal policy sebagai "suatu ilmu sekaligus seni yang bertujuan untuk memungkinkan peraturan hukum positif (dalam hal ini hukum pidana) dirumuskan secara lebih baik" Dalam rangka memaksimalkan upaya pencegahan kejahatan dalam masyarakat karena sumber/penyebab terjadinya perilaku meyimpang, terutama dalam kehidupan beragama sangat komplek, dan jika hanya bertumpu pada hukum pidana/ penal tentu belum cukup.

Berdasarkan hal-hal tersebut diatas, dilihat dari sudut "criminal policy", upaya penanggulangan kejahatan (termasuk penanggulangan aliran sesat) tentunya tidak dapat dilakukan secara parsial dengan hukum pidana (sarana "penal"), tetapi harus ditempuh pula dengan pendekatan integral/sistemik. Dengan demikian, jika faham radikal ini diasumsikan/ dipersamakan sebagai bagian dari "tindak pidana terhadap agama dan tindak

$$
67 \text { Ibid. }
$$

pidana yang berhubungan dengan agama", maka adalah wajar jika upaya penanggulangannya ditempuh melalui pendekatan agama (religion Approach) di samping pendekatan budaya/kultural, pendekatan moral/edukatif, dan lain sebagainya.

\section{G. Metode Penelitian}

\section{Spesifikasi Penelitian}

Berdasarkan permasalahan yang diteliti oleh penulis, maka penulis menggunakan metode penelitian hukum normatif. Metode penelitian hukum normatif atau metode penelitian hukum kepustakaan adalah metode atau cara yang dipergunakan di dalam penelitian hukum yang dilakukan dengan cara meneliti bahan pustaka yang ada"67. Selanjutnya adalah menggunakan hukum empiris yaitu penelitian hukum berdasarkan lapangan. Secara spesifik bahwa penelitian ini adalah penelitian kualitatif, yaitu penelitian yang menggambarkan kondisi objektif yang ada di lapangan.

Penelitian ini bukan saja menggambarkan suatu keadaan atau gejala, baik pada tataran hukum positif maupun empiris tetapi juga ingin memberikan pengaturan yang seharusnya (das Sollen) dan memecahkan permasalahan hukum yang berkaitan dengan peran Satuan Intelkam dalam upaya Deradikalisasi di Deli Serdang

\section{Metode Pendekatan}

Setelah menggunakan metode penelitian hukum normatif, selanjutnya untuk mendapatkan informasi dan jawaban dari masalah yang dirumuskan penulis

${ }^{67}$ Soerjono Soekanto dan Sri Mamudji, enelitian Hukum Normatif Suatu Tinjauan Singkat, (Cetakan ke - 11. Jakarta : PT Raja Grafindo Persada, 2009,), h. 13 
Media Komunikasi dan Informasi Hukum dan Masyarakat

menggunakan pendekatan komparatif (comparative approach)"68. Pendekatan ini dilakukan dengan melihat adanya persamaa substansi menegenai hak asasi manusia yang merupakan kebutuhan secara universal.

Penelitian ini dikategorikan sebagai penelitian hukum bersifat yuridis empiris (penelitian hukum kepustakaan), yaitu dengan cara meneliti bahan pustaka atau data sekunder belaka, yang mencakup penelitian terhadap asas-asas hukum, sistematika hukum, sinkronisasi hukum, sejarah hukum, perbandingan hukum", ${ }^{67}$ serta hukum yang akan datang (futuristik). ${ }^{68}$ Sebagai penelitian hukum normatif, penelitian ini juga berupaya untuk meneliti data primer, yang dikenal sebagai penelitian hukum yuridis empiris". ${ }^{69} \mathrm{Di}$ dalam penelitian hukum normatif, maka penelitian terhadap azas-azas hukum dilakukan terhadap kaidah-kaidah hukum, yang merupakan patokan-patokan berperilaku atau bersikap tidak pantas. Penelitian tersebut dapat dilakukan terutama bahan hukum primer dan sekunder yang mengandung kaidahkaidah hukum. Penelitian terhadap sistematik hukum adalah khusus terhadap bahan-bahan hukum primer dan sekunder. Kerangka acuan yang dipergunakan adalah pengertian dasar dalam sistem hukum.

Penelitian terhadap taraf sinkronisasi vertikal dan horizontal bertujuan untuk mengungkapkan kenyataan, sampai sejauhmana perundang-undangan tertentu serasi secara vertikal, atau mempunyai keserasian secara horizontal dengan

\footnotetext{
68 Ibid, h.15

${ }^{67}$ Bambang Sunggono, Metodologi Penelitian Hukum, (Raja Grafindo Persada, Jakarta, 2003), h.50-51.

${ }^{68}$ C.F.G. Sunaryati Hartono, Penelitian Hukum di Indonesia pada akhir Abad ke-20, (Bandung: Alumni, 1994), h.144.

${ }^{69}$ Soerjono Soekanto dan Sri Marmudji, Penulisan Hukum Normatif, (Jakarta: Rajawali, 1986), h.15.
}

perundang-undangan yang sederajat mengenai bidang yang sama. Sedangkan penelitian hukum terhadap perbandingan hukum, biasanya merupakan penelitian sosiologi hukum, antropologi hukum, psikologi hukum, dan seterusnya. Sebagaimana halnya dengan perbandingan hukum, maka sejarah hukum berusaha untuk mengadakan identifikasi terhadap tahap-tahap perkembangan hukum, yang dapat dipersempit ruang lingkupnya menjadi sejarah perundangundangan.

Adapun jenis data yang dibutuhkan dalam penelitian ini adalah data sekunder yaitu bahan-bahan pustaka. Dengan demikian, data ini bersumber dari kepustakaan, yaitu bahan hukum primer, bahan hukum sekunder dan bahan hukum tersier. Berdasarkan jenis dan sumber data tersebut, maka penelitian ini lazim disebut penelitian kepustakaan (library research).

Sebagai penunjang bagi data sekunder tersebut, penelitian ini juga membutuhkan data primer, yakni data yang diperoleh secara langsung dari lapangan, masyarakat dan pemerintah. Data-data yang dimaksud adalah hasil survey dan wawancara yang dilakukan di Satuan Intelkam Deli Seerdang

Substansi dalam tulisan ini tentang Peran Satuan Intelkam Dalam Mencegah Paham Radikal di Masyarakat Melalui Deradikalisasi (Studi Penelitian Satuan Intelkam Polres Deli Serdang).

\section{Sumber Data}

Sumber data dalam penelitian ini adalah data sekunder. Data sekunder adalah data yang diperoleh dari hasil penelitian pustaka, yakni berupa peraturan perundangundangan, dokumen-dokumen yang terkait dengan Undang-undang tentang intelijen 
Media Komunikasi dan Informasi Hukum dan Masyarakat

negara, serta literatur-literatur hasil penelitian yang ada hubungannya dengan masalah yang akan dibahas.

\section{Prosedur Pengumpulan Data}

Untuk memperoleh data yang dilakukan penulis dalam penulisan tesis ini, berupa data sekunder, maka penulis mengadakan kegiatan yang pada umumnya digunakan dalam penelitian hukum, yaitu:

1. Studi Pustaka

Studi pustaka dilakukan dengan cara menginventarisasikan dan mengutip bukubuku literatur ilmu hukum, ketentuan perundang-undangan, serta karangankaranagan ilmiah dan catatan-catatan kuliah yang ada kaitannya dengan penulisan tesis ini. Serta dengan cara membaca, mempelajari, mengutip dan menghimpun data yang diperoleh dari buku literatur, serta peraturan-peraturan lainnya yang berhubugan dengan permasalahan yang akan di bahas.

2. Wawancara

Dalam hal ini peneliti melakukan wawancara langsung ke lapangan terhadap informan yang dapat memberikan jawaban terhadap permasalahan yang diteliti.

Adapun informan atau nara sumber dalam penelitian ini adalah :

- Dirintelkam

- Satintelkam

- Anggota Satuan Intelkam

3. Pengelolahan Data

Data yang terkumpul dari studi kepustakaan diperiksa, diteliti dan disusun kembali secara seksama. Data tersebut diklasifikasikan menurut bidang masingmasing dan diperiksa, kemudian dipersiapkan untuk dianalisa. Data yang telah terkumpul selajutnya diolah dengan cara :

a. Seleksi data yaitu memilih data sesuai dengan topik yang akan dibahas.

b. Klasifikasi data yaitu mengelompok data sesuai dengan penempatan data dalam hubunganya dengan permasalahan yang dibahas.

c. Sistematika data yaitu penyusunan data yang dilakukan secara sistematik dan sesuai dengan konsep, tujuan dan pokok bahasan.

\section{Analisis Data}

Proses terakhir dalam rangka penyusunan tesis ini adalah proses analisa data yang merupakan usaha untuk menemukan jawaban dari permasalahan dan hal-hal yang akan diperoleh dari penelitian pendahuluan. Rangkaian data disusun secara sistematis menurut klasifikasinya sehingga mudah dimengerti, dipahami, serta merupakan jawaban dari permasalahan yang $\mathrm{ada}^{70}$. Data tersebut kemudian diuraikan ke dalam bentukbentuk kalimat yang tersusun secara sitematis.

\section{PEMBAHASAN}

A. Peran Intelkam Dalam Mencegah Paham Radikalismedi Kabupaten Deli Serdang

Dalam aplikasi sistem pemerintah Indonesia peranan intelijen adalah memberikan peringatan (early detection and early warning system) tentang hal-hal yang berkaitan dengan ancaman terhadap negara dari dalam maupun dari luar. Secara yuridis maka peran intelijen jika diterjemahkan dari tujuan Intelijen Negara yang tertulis dalam UU Nomor 17 tahun 2011

${ }^{70}$ Abdulkadir Muhammad. Hukum Dan Penelitian Hukum. (Bandung: PT. Citra Aditya Bakti. 2004), h. 66 
Media Komunikasi dan Informasi Hukum dan Masyarakat

tentang Intelijen Negara Pasal 5 disebutkan bahwa: Tujuan Intelijen Negara adalah mendeteksi, mengidentifikasi, menilai, menganalpaham radikal, menafsirkan, dan menyajikan Intelijen dalam rangka memberikan peringatan dini untuk mengantisipasi berbagai kemungkinan bentuk dan sifat ancaman yang potensial dan nyata terhadap keselamatan dan eksistensi bangsa dan negara serta peluang yang ada bagi kepentingan dan keamanan nasional.

$\begin{array}{ccc}\text { Secara umum fungsi } & \text { sebuah } \\ \text { organisasi intelijen negara adalah }\end{array}$
mengamankan kepentingan nasional. Berkaitan dengan paham radikal yang terjadi di Indonesia yang merupakan salah satu ancaman yang mengganggu kepentingan nasional, maka intelijen wajib berperan serta dalam mencegah, menanggulangi dan memberantas paham radikal. Intelijen tidak memiliki kewenangan dalam bidang penegakan hukum. Jika intelijen menemukan alat bukti yang menyangkut tentang pencegahan, penangkalan, dan penanggulangan ancaman keamanan nasional maka dilakukan koordinasi dengan pihak lain seperti kepolisian untuk penegakan hukum.

Berdasarkan tugas dan kewenangannya maka intelijen mempunyai peran yang sangat vital dalam penganggulangan paham radikal. Sesuai dengan Pasal 7 UU Nomor 17 tahun 2011 tentang Intelijen Negara maka ruang lingkup intelijen negara adalah Intelijen dalam negeri dan luar negeri, Intelijen pertahanan dan/atau militer, Intelijen Kepolisian, Intelijen penegakan hukum, dan Intelijen kementrian/lembaga pemerintah nonkementrian. Intelijen pertahanan/militer di Indonesia berada dalam organisasi BAIS (Badan Intelijen Strategis
TNI). Dalam organisasi BAIS TNI, yang sudah mempunyai sejarah perkembangan cukup panjang dan berpengalaman, terdapat potensi intelijen yang sangat besar. Intelijen militer adalah unsur yang sudah lama ada dan terlatih beriringan dengan masa keberadaan negara Indonesia. Setelah peristiwa reformasi 1998 keberadaan intelijen militer di tubuh TNI mulai terduksi mengikuti TAP MPR NO. VII/2000 yang menyebutkan bahwa peran TNI merupakan alat pertahanan negara, bertugas pokok mempertahankan negara. Hal ini sangat tegas untuk membagi kewenangan dengan POLRI yang mempunyai tugas untuk menjaga keamanan negara dan keutuhan wilayah NKRI. Dengan landasan ini maka ancaman paham radikal menjadi tugas utama Polri untuk menanganinya.

Presiden Indonesia ke 6 Susilo Bambang Yudhoyono (2004-2014) yang telah menginisiasi pembentukan BNPT (Badan Nasional Penanggulangan Paham radikal) mempunyai strategi untuk mengedepankan elit polisi didukung $\mathrm{TNI}$ dalam menangani paham radikal. TNI yang berperan pada lapis kedua mempunyai kekuatan dan personel dengan kemampuan anti teror yang sudah teruji. TNI$A D$ mempunyai Satuan Penanggulangan Teror atau disebut Sat Gultor-81 Kopassus. Detasemen Jala Mengkara yang dimiliki oleh TNI-AL dan Detasemen Bravo-90 yang dimiliki oleh TNI-AU tidak kalah pamor dan kualitas dengan saudaranya di TNI-AD. Personel dari $\mathrm{TNI}$ dengan kemampuan anti teror ini terlalu disayangkan jika tidak dimanfaatkan dengan baik oleh negara dalam penanggulangan paham radikal.

Polri sebagai lembaga yang mempunyai kewenangan dalam penindakan hukum membentuk Satuan Tugas Anti Teror 
Media Komunikasi dan Informasi Hukum dan Masyarakat

bernama Detesamen Khusus 88 Anti Teror POLRI (Densus 88/AT). Tugas Densus 88/AT adalah menangani segala bentuk ancaman teroris termasuk diantaranya ancaman bom dan penyanderaan. Dalam menangani ancaman dan aksi teroris, Densus 88/AT memerlukan laporan intelijen sebagai informasi awal untuk melakukan tindakan.

Intelijen menjadi salah satu kunci pemberantasan tindak pidana paham radikal. Bukti awal dari laporan intelijen memberikan kewenangan Densus 88/AT untuk melakukan penangkapan. Fungsi intelijen dalam struktur organisasi dari Densus 88/AT sangat strategis. Densus 88/AT dalam organisasinya memiliki empat pilar pendukung operasional setingkat sub-detasemen (Subden), yakni: Subden Intelijen, Subden Penindakan, Subden Investigasi, dan Subden Perbantuan.

Di bawah Subden terdapat unit-unit yang menjadi pondasi pendukung bagi operasional Densus 88/AT, seperti pada Subden Intelijen terdapat Unit Analisa, Deteksi, Unit Kontra Intelijen, pada Subden Penindakan terdapat Unit Negoisasi, Pendahulu, Unit Penetrasi, dan Unit Jihandak. Sedangkan pada Subden Investigasi membawahi Unit Olah TKP, Unit Riksa, dan Unit Bantuan Teknis, terakhir pada Subden Bantuan terdapat Unit Bantuan Operasional dan Unit Bantuan Administrasi.

Personel Densus 99/AT sudah dilengkapi kemampuan intelijen pengamanan. Kemampuan tersebut sangat penting untuk diaplikasikan dalam menangani paham radikal. Tindakan-tindakan yang dilakukan oleh aparat negara dalam menangani paham radikal sering kali membuat berbagai pihak cenderung resisten. Untuk menghindari hal tersebut maka perlu dilakukan analpaham radikal-analpaham radikal dan metode intelijen sehingga menjadi bahan acuan dalam melakukan operasi penanaganan paham radikal yang lebih tepat sasaran dan humanis dengan tetap mengedepankan keselamatan rakyat di atas segalanya.

Perspektif intelijen dalam penanggulangan paham radikal diperlukan dalam spektrum strategis. Kemampuan intelijen untuk mencari informasi, mengolah informasi dan menyajikan informasi untuk pengambilan keputusan sangat diperlukan dalam mendukung langkah-langkah penanggulangan paham radikal. Informasi intelijen sangat diperlukan mengingat aksi paham radikal disusun dan dilakukan secara tertutup dengan metode klandestin (kegiatan rahasia).

Kelompok paham radikal bergerak secara rahasia. Untuk membaca dan menganalpaham radikal gerakan tersebut diperlukan kemampuan intelijen dan kontra intelijen. Hal ini tentu harus dilakukan oleh petugas yang cakap dan kompeten sehingga dalam penindakan dan penanggulangan paham radikal dapat dilakukan secara tepat dan efektif. Salah satu usaha efektif untuk mencegah paham radikal adalah dengan deradikalisasi. Secara sederhana deradikalisasi dapat diartikan sebagai suatu usaha untuk membuat orang tidak radikal. Sasaran dari program deradikalisasi adalah teroris yang sudah tertangkap, bekas teroris, kelompok potensial yang bisa direkrut teroris maupun masyarakat umum.

Peran merupakan sebuah konsepsi yang menunjukan kedudukan dan memunculkan konsekuensi berupa tindakan yang terkonstruksi berdasarkan kedudukan yang disandangnya. Berkaitan dengan peran, 
Media Komunikasi dan Informasi Hukum dan Masyarakat

Polres Deli Serdang tentu saja bisa dilihat peranya dalam penanggulangan paham radikal di Kabupaten Deli Serdang. Secara konseptual, Hikam menyatakan bahwa "peranan yang berhubungan dengan pekerjaan, seseorang diharapkan menjalankan kewajiban-kewajibanya yang berhubungan dengan peranan yang dipegangnya "1.

Apabila dikaitkan dengan peran Polres Deli Serdang dalam penanggulangan paham radikal, Polres Deli Serdang telah melakukan perannya sebagai penegak hukum yang bekerja berdasarkan peraturan perundangundangan yang berlaku. Sehingga secara tidak langsung peran dari Polres Deli Serdang dalam penanggulangan paham radikal terbatas dengan peraturan yang berlaku. Alvin L. Bertran menyebutkan bahwa peranan adalah pola tingkah laku yang diharapkan dari orang yang memangku status atau kedudukan tertentu ${ }^{2}$.

Polres Deli Serdang sebagai penegak hukum sudah mempunyai pola tingkah laku yang diharapkan oleh masyarakat sebagai penegak hukum, atau sebagai pengawas masyarakat. Namun apabila dikaitkan dengan penanggulangan paham radikal secara yuridis formal, Polres Deli Serdang telah melakukan cara dan memiliki tindakan yang sesuai dengan peraturan yang berlaku, akan tetapi penyelesaian masalah paham radikal tidak cukup diselesaikan hanya dengan pelaksanaan peraturan yang ada, karena permasalahan paham radikal lebih mengarah pada permasalahan sosial yang memerlukan

${ }^{1}$ Hikam, Muhammad (2016). Deradikalisasi : peran masyarakat sipil Indonesia membendung radikalisme. Jakarta: Penerbit Buku Kompas. ISBN 9789797099855. OCLC 934509967.

${ }^{2}$ Alvin, (2016). Peran Masyarakat Sipil Indonesia Membendung Radikalisme - DERADIKALISASI. Jakarta: Kompas. hlm. 163 penyelesaian dengan pendekatan kultural, bukan struktural. Sebab, tindakan kepolisian dalam hal ini Polres Deli Serdang sebagai penegak hukum sering menggunakan tindakan represif terhadap para pelaku paham radikal, sehingga pengaruh paham radikal akan berkembang lebih masif dari sebelumnya.

Hal ini disebabkan karena pola perilaku kepolisian hanya menimbulkan rasa takut tanpa memunculkan rasa kesadaran diri dari masyarakat khususnya yang menjadi anggota teroris mengenai bahaya aksi paham radikal dan paham radikalisme. Selain itu, Glen Elder dalam pendekatan "life-course" memaknakan bahwa setiap masyarakat mempunyai harapan kepada setiap anggotanya untuk mempunyai perilaku tertentu sesuai dengan kategori-kategori usia yang berlaku dalam masyarakat tersebut. ${ }^{3}$ Konsep ini lebih mengedepankan pada faktor usia sebagai unsur pembeda terhadap suatu perilaku tertentu. Institusi kepolisian dalam hal ini Polres Deli Serdang merupakan bagian dari masyarakat yang tidak bisa lepas dengan pola perilaku yang berlaku di masyarakat.

Secara tidak langsung dapat dikatakan bahwa Polres Deli Serdang harus menyesuaikan diri terhadap pola-pola perilaku yang berlaku. Akan tetapi status Polres Deli Serdang yang merupakan salah satu bagian dari masyarakat berbenturan dengan status kepolisian dalam hal ini Polres Deli Serdang sebagai alat negara yang cenderung taat dan patuh terhadap konstitusi yang berlaku. Konflik peranan tersebut menyebabkan tindakan dari kepolisian dalam hal ini Polres Deli Serdang dalam penanggulangan paham radikal tidak

\footnotetext{
${ }^{3}$ Glen Elder, Deradikalisasi Terhadap Teroris, Jakarta : Bumi Aksara, 2014, hlm.37
} 
Media Komunikasi dan Informasi Hukum dan Masyarakat

efektif karena status yang disandang oleh Polres Deli Serdang saling bertolak belakang.

Cara merupakan preferensi dari seseorang untuk melakukan sesuatu yang diwujudkan melalui tindakan nyata yang berdampak pada terciptanya tujuan yang akan di capai. Dalam penanggulangan pengaruh paham radikal, Polres Deli Serdang mencoba melakukan tindakan-tindakan pencegahan dengan pendekatan sosial. Karena mengingat tindak kriminal dari para anggota paham radikal di Indonesia belum mengarah kepada tindakan kriminal yang menyalahi hukum di Indonesia. Cara dari Polres Deli Serdang tersebut disampaikan oleh AKP Amir Sinaga,

SH, Kasat Intelkam Polres Deli Serdang.

1. Pertama dalam penanggulangan pengaruh paham radikal di Deli Serdang, cara yang efektif adalah dengan melihat akar munculnya paham radikalisme dan mengklasifikasikanya kedalam beberapa kategori menurut bidang kehidupan masyarakat yaitu radikalisme dalam bentuk ideologi, radikalisme dalam bentuk agama, radikalisme dalam bentuk ekonomi dan radikalisme dalam bentuk sparatis. Masingmasing kategori tersebut tentu memiliki pola penanganan yang berbeda-beda

2. Melakukan pemetaan terhadap kelompok paham radikalisme di tengah-tengah masyarakat.

3. Melakukan pemetaan dan pendataan terhadap kelompok paham radikalisme

4. Melakukan pendeteksian terhadap gerakan paham radikalisme yang ada di wilayahnya.

5. Melakukan penangkapan terhadap kelompok terorisme atau pelaku penyebaran paham radikalisme. ${ }^{4}$

$$
\text { Polres Deli Serdang dalam }
$$

penanggulangan pengaruh paham radikal tentu akan lebih mudah melakukan tindakantindakan pencegahan dengan mengetahui terlebih dahulu akar permasalahan tersebut muncul. Secara lebih spesifik, harus

\footnotetext{
${ }^{4}$ Wawancara dengan AKP Amir Sinaga,SH
} Kasat Intelkam Polres Deli Serdang,4 Mei 2019 memahami terlebih dahulu bentuk radikalisme serta sumber munculnya radikalisme tersebut. Sehingga arah penangananya menjadi lebih mudah dan efektif. Pernyataan tersebut dilengkapi dengan pernyataan dari Ipda K. Sinurat Kepala Seksi Pengawasan Intel Polres Deli Serdang.

".Adapun peran Polres Deli Serdang
melalui cara yang efektif adalah
dengan melibatkan para tokoh
masyarakat, tokoh agama dan tokoh
adat, guru, dosen dan instansi terkait
untuk bertanggungjawab mencegah
masyarakat melalui pembinaan..."

Dengan melibatkan tokoh agama, tokoh masyarakat dan tokoh adat merupakan strategi dalam pencegahan pengaruh paham radikal untuk memanfaatkan tokoh panutan lokal agar mampu memberikan sugesti kepada masyarakat dengan harapan masyarakat tidak mudah mendapat hasutan dari pihak-pihak lain yang membawa paham radikal. Cara tersebut dinilai lebih efektif, disamping menumbuhkan fungsi advokasi dari dalam masyarakat sendiri melalui tokoh-tokoh lokal, lingkup kerja dari Polres Deli Serdang pun menjadi lebih sempit sehingga waktu dan capaiannya pun akan lebih efektif dan efisien. Hal ini senada dengan pernyataan dari AIPDA J. Tarigan, anggota Polres Deli Serdang.

"Peran Polres Deli Serdang dalam menanggulangi paham radikalisme dianggap cara yang efektif untuk menanggulangi paham radikal adalah dengan melakukan penyuluhan dan pembinaan di masyarakat..."6

Pernyataan tersebut menunjukan bahwa memang pada saat ini langkah yang tepat untuk menanggulangi paham radikal di Kabupaten Deli Serdang adalah dengan

\footnotetext{
${ }^{5}$ Wawancara dengan IPDA K.Sinurat, Ka.Seksi Pengawas Intelkam, ,4 Mei 2019

${ }^{6}$ Wawanara dengan AIPDA J. Tarigan, Anggota Intelkam, 13 Mei 2019
} 
Media Komunikasi dan Informasi Hukum dan Masyarakat

melakukan penyuluhan dan pembinaan pada masyarakat untuk memberikan informasi kepada masyarakat mengenai bahaya paham radikal. Namun pada dasarnya langkah atau cara tersebut belum cukup untuk mengatasi permasalahan mengenai masuknya pengaruh paham radikal di Kabupaten Deli Serdang.

Berdasarkan uraian tersebut dapat disimpulkan bahwa dalam penanggulangan pengaruh paham radikal di Kabupaten Deli Serdang, selama ini Polres Deli Serdang telah melakukan berbagai cara. Cara yang menonjol dalam penanggulangan pengaruh paham radikal tersebut dengan cara bekerja sama dengan tokoh masyarakat, tokoh agama, dan tokoh adat serta tokoh-tokoh lokal yang menjadi panutan masyarakat setempat untuk melakukan pembinaan dan penyuluhan kepada masyarakat dengan harapan mampu membendung pengaruh paham radikal di masyarakat khususnya masyarakat Kabupaten Deli Serdang.

Berdasarkan hasil penelitian yang dilakukan dengan wawancara dengan berbagai pihak, maka dapat diidentifikasi bahwa peran Satuan Intelkam dalam melakukan tindakan hukum terhadap paham radikal secara umum sesuai dengan wawancara penulis dengan AIPDA J. Tarigan selaku anggota Intelkam Polres Deli Serdang adalah :

1. Tugas kepolisian dalam penanggulangan paham radikal khususnya penanganan paham radikal adalah melakukan pendataan, penggalangan terhadap kelompok atau keluarga yang diduga sudah masuk ke dalam propaganda paham radikal.

2. Melakukan pencegahan masyarakat yang melakukan eksodus ke luar negeri untuk bergabung dengan kelompok paham radikal, melakukan penangkapan kepada pelaku kriminal yang dilakukan anggota atau partisipan paham radikal.

3. Melakukan penangkapan bersama Densus 88 terhadap pelaku paham radikalisme
4. Mengajukan ke pengadilan terhadap pelaku teroris atau penyebar paham radikal.

5. Menjadi saksi dalam pengajuan ke pengadilan terhadap pelaku kelompok teroris atau paham radikal lainnya

6. Memberikan tindakan hukum sesuai dengan undang-undang terhadap pelaku penyebar paham radikalisme. ${ }^{7}$

Adapun peran Polres Deli Serdang

terhadap kelompok-kelompok yang dianggap

rentan terhadap masuknya paham radikal di

Kabupaten Deli Serdang yang diidentifikasi

oleh pihak Kepolisian, dalam pantauan Satuan

Intelkam adalah :

1. Kelompok yang rentan terhadap pengaruh radikalisme ialah $\mathrm{FPI}, \mathrm{HTI}$, LDII, serta kelompok/aliran yang cenderung eksklusif.

2. Kelompok premanisme, kelompok penganut ajaran agama tertentu yang sangat fanatik, kelompok pelajar atau mahasiswa yang berlatarbelakang pertumbuhan ekonomi

3. Orang-orang miskin yang mudah dipengaruhi dan orang-orang yang baru mulai sadar untuk bertobat dan ingin segera mendapat pengampunan dosany ${ }^{8}$

Oleh karena itu Satuan Intelkam Polres

Kabupaten Deli Serdang memiliki peran strategis dalam upaya menghadapi paham radikalisme yang sudah diidentifikasikan di berbagai tempat.

Adapun strategi yang dilakukan oleh AIPDA J. Tarigan Satuan Intelkam Polres Deli Serdang adalah sebagai berikut :

1. Strategi yang diterapkan saat ini adalah berpedoman pada kebijakan pimpinan Polri yang mengedepankan akselerasi terhadap pelayanan publik, mengedepankan peran Binmas sebagai pemberi dan penggalang masyarakat, mengedepankan fungsi Intelkam dalam melakukan deteksi-deteksi dini gangguan ancaman yang akan terjadi, mengedepankan peran Reskrimum dalam penindakan pelaku kejahatan kriminal, mengedepankan peran Sabhara/Brimob sebagai penegakan hukum anti kerusuhan massa, serta mengedepankan peran Humas dalam penyampaian berita

\footnotetext{
${ }^{7}$ Ibid

${ }^{8}$ Ibid
} 
Media Komunikasi dan Informasi Hukum dan Masyarakat

2. Pelaksanaan strategi tersebut yaitu berupa pemetaan dan pendataan kelompokkelompok radikal, melakukan pembinaan dan penyuluhan kepada masyarakat, berusaha bersinergi dengan instansiinstansi lain yang terkait

3. Melakukan pendataan dan penggolongan kepada masyarakat dan melakukan pemetaan wilayah yang rawan konflik. $^{9}$

Demikian juga hasil wawancara

penulis dengan Bapak Wawanara dengan

AIPDA J. Tarigan, Anggota Intelkam, 13 Mei

2019 bahwa :

1. Dalam penanggulangan pengaruh paham radikal di Deli Serdang, cara yang efektif adalah dengan melihat akar munculnya paham radikalisme dan mengklasifikasikanya kedalam beberapa kategori menurut bidang kehidupan masyarakat yaitu radikalisme dalam bentuk ideologi, radikalisme dalam bentuk agama, radikalisme dalam bentuk ekonomi dan radikalisme dalam bentuk sparatis. Masingmasing kategori tersebut tentu memiliki pola penanganan yang berbeda-beda.

2. Melibatkan para tokoh masyarakat, tokoh agama dan tokoh adat, guru, dosen dan instansi terkait untuk bertanggungjawab mencegah masyarakat melalui pembinaan

3. Dengan melakukan monitoring giat, koordinasi dengan pihak terkait, melakukan pendekatan dan penggalangan, apabila kegiatan paham radikal semakin mengkhawatirkan melaksanakan tindakan yang dianggap perlu.

4. Polres Deli Serdang bisa sebagai motivator dalam menggerakan tokoh agama, tokoh masyarakat untuk berperan aktif dalam penanggulangan paham radikal.

5. Polres Deli Serdang adalah sebagai aprat penegak hukum yang melindungi masyarakat dari ancaman teror dan menolong masyarakat untuk tidak terjerumus dalam lingkaran ideologi paham radikal dan melakukan penegakan hukum terhadap pelaku kriminal.

6. Memberdayakan peran Babinkamtibmas dalam pembinaan di setiap desa, memberdayakan para tokoh masyarakat, tokoh agama dan tokoh adat dalam berpartisipasi untuk pembinaan, menyelenggarakan workshop atau sarasehan dan penyuluhan dalam mencegah radikalisme, menindak tegas kelompok radikalisme yang anarkis.

\footnotetext{
${ }^{9}$ Wawancara dengan IPDA K.Sinurat, Ka.Seksi Pengawas Intelkam, ,4 Mei 2019
}

Bagi pelaku terorisme atau paham radikal yang nyata-nyata melakukan terror maka kepolisian melakukan tindakan sesuai dengan peratuan perundang-undangan yang berlaku yaitu Undang-Undang No.15 Tahun 2003 tentang teorisme Pasal 6:

Setiap orang yang dengan sengaja menggunakan kekerasan atau ancaman kekerasan menimbulkan suasana teror atau rasa takut terhadap orang secara meluas atau menimbulkan korban yang bersifat massal, dengan cara merampas kemerdekaan atau hilangnya nyawa dan harta benda orang lain, atau mengakibatkan kerusakan atau kehancuran terhadap obyek-obyek vital yang strategis atau lingkungan hidup atau fasilitas publik atau fasilitas internasional, dipidana dengan pidana mati atau penjara seumur hidup atau pidana penjara paling singkat 4 (empat) tahun dan paling lama 20 (dua puluh) tahun. ${ }^{10}$

Berbagai peran sebagaimana diuraikan di atas adalah peran Intelkam Polres Deli Serdang dalam melakukan tindakan terhadap paham radikalisme yang ada di wilayah hukum Polres Deli Serdang.

\footnotetext{
10 lbid
} 
Media Komunikasi dan Informasi Hukum dan Masyarakat

\section{Daftar Bacaan}

Abdulkadir Muhammad. Hukum Dan Penelitian Hukum. (Bandung: PT. Citra Aditya Bakti. 2004)

Abdul, Munip, Paham Radikalisme, http://solobook.wordpress.com

Agus Andrianto, Cegah Faham Radikalisme Polda Sumut Resmikan Galeri Perdamaian, (Polda Sumut, Medan Hedlines Com, 01-01-2018)

Ali Mudhofir, Radikalisme, (Jakarta : IImu Kalam, 2011)

A.S., Hikam, Muhammad, Deradikalisasi : Peran Masyarakat Sipil Indonesia Membendung Radikalisme. (Jakarta: Penerbit Buku Kompas, 2016)

Azra, Azyumardi, "Akar radikalisme keagamaan peran aparat negara, pemimpin agama dan guru untuk kerukunanumatberagama", makalah dalam workshop "Memperkuat Toleransi Melalui Institusi Sekolah"2011.

BNPT, Program Deradikalaisasi, (Jakarta : BNPT, 2017)

Cahya Suryana, Tugas Pokok dan Fungsi Intelijen Keamanan (Satintelkam),(Sebuah Artikel, 2012).

Hikam, Muhammad A.S. Peran Masyarakat Sipil Indonesia Membendung Radikalisme - Deradikalisasi. (Jakarta: Kompas. 2016)

Indonesia, CNN. "Jokowi Pamer Kesuksesan Deradikalisasi Indonesia di KTT G20". CNN Indonesia (dalam bahasa Inggris). Diakses tanggal 2017-10-02.

I Gde Arya Wibawa, Sambangi Tokoh Agama Cegah Radikalisme, (Bali : Sat Intelkam Denpasar, 2017)

Leila Ezzarque, Proses Deradikalisasi, (Jakarta : Kencana, 2015)

Muslich, Pergerakan Paham Radikalisme, (Jakarta : Kencana, 2015), h.9

Priyo Widyanto, Tugas Pokok dan Fungsi Intelkam, (Balikpapan : Kapolres Balikpapan, 2012)
Petrus Reinhard Golose, Deradikalisasi Terorisme, (Jakarta : YPKIK, 2009)

Poerwadarminta, Kamus Besar Bahasa Indonesia, (Jakarta : Balai Pustaka,

Rusman Hadi, Polri Menuju Reformasi, (Jakarta : Yayasan Tenaga Kerja, Baintelkam POLRI, 2012)

Robert Da Costa, Tiga Wilayah di Deli Serdang Terkontaminasi Radikalisme, (Jakarta, Netralnews.Com, Penulis, Juven Martua Sitompul, Rabu, 20 Sep 2017 )

Salito Wiryawan, Paham Radikal Paham Kiri, (Jakarta : Kencana, 2013)

Soerjono Soekanto dan Sri Mamudji, Penelitian Hukum Normatif Suatu Tinjauan Singkat, (Cetakan ke - 11. Jakarta : PT Raja Grafindo Persada, 2009)

Sosiologi Suatu Pengantar, (Jakarta : Rajawali Pers, 2002)

Soepomo Soegirman, Inteligen Profesi Untuk Orang-orang Aneh, (Jakarta : Bumi Aksara, 2011)

Saronto, Y.Wahyu, Intelijen, Teori dan Aplikasi dan Modernisasi, (Jakarta : Ekalaya Saputra, 2001)

Suparlan, Menuju Masyarakat Indonesia yang Multikultural, 2009, Diakses dari Situs $\mathrm{http} /$ wwww.duniaesai.com/antra.htm.2008

Stainislaus Riyatna, Kajian Stratejik Intelijen, (Jakarta UI:Jurnallnelijen, 2015)

Tito Karnavian, Lima Langkah Deradikalisasi, (Jakarta : Netralnewscom, 2017)

WJS. Poerwadarminta, Kamus Umum Bahasa Indonesia, (Jakarta : Balai Pustaka, 2006)

Zaenal Arifin, Meluruskan Pengertian Radikal. (Jakarta : Kencana, 2013)

\section{Undang-Undang}

UU Republik Indonesia No.17 Tahun 2011 tentang Intelijen Negara,

Penetapan Pemerintah No. 11/S.D tahun 1946, tugas pokoknya Intelijen.

Pasal 30 Ayat (4) Undang-Undang Dasar 1945 
Media Komunikasi dan Informasi Hukum dan Masyarakat

\section{Media}

https://www.islampos.com/ini-pengertianradikal-menurut-akademisi-90337/
Pusbangdatin. "Detailpost - Program Deradikalisasi sebagai upaya Pencegahan Terjadinya Tindakan Terorisme di Indonesia". Badan Penelitian dan Pengembangan Hukum dan HAM I Kementerian Hukum dan HAM Republik Indonesia (dalam bahasa Inggris). Diakses tanggal 2017-10-02.

Media, Kompas Cyber. "Jokowi Bentuk Unit Kerja Pembinaan Pancasila Kompas.com". KOMPAS.com (dalam bahasa Inggris). Diakses tanggal 201710-02

Pusbangdatin. "Detailpost - Program Deradikalisasi sebagai upaya Pencegahan Terjadinya Tindakan Terorisme di Indonesia". Badan Penelitian dan Pengembangan Hukum dan HAM I Kementerian Hukum dan HAM Republik Indonesia (dalam bahasa Inggris). Diakses tanggal 2018

Media Dunia News, Co, Polres Deli Serdang terima Kunjungan Tim dari Div Humas Mabes Polri, Deli Serdang, 2018 